\title{
A chemical and microbial characterization of selected mud volcanoes in Trinidad reveals pathogens introduced by surface water and rain water
}

Dirk Schulze-Makuch (ㄴ) https://orcid.org/0000-0002-1923-9746, Shirin Haque 난 https://orcid.org/0000-0002-9158-7091, Denise Beckles, Philippe Schmitt-Kopplin (1) https://orcid.org/0000-0003-0824-2664, Mourad Harir, Beate Schneider, Christine Stumpp (i) https://orcid.org/0000-0001-9041-2735, Dirk Wagner (i) https://orcid.org/0000-00015064-497X

DOI

10.1016/j.scitotenv.2019.136087

Original publication date

13 December 2019 (Available online)

Document version

Accepted manuscript

Published in

Science of The Total Environment

\section{Citation}

Schulze-Makuch D, Haque S, Beckles D, Schmitt-Kopplin P, Harir M, Schneider B, et al. A chemical and microbial characterization of selected mud volcanoes in Trinidad reveals pathogens introduced by surface water and rain water. Science of The Total Environment. 2020;707:136087. 
A Chemical and Microbial Characterization of Selected Mud Volcanoes in Trinidad

3

4 Dirk Schulze-Makuch ${ }^{1,2,3}$, Shirin Haque ${ }^{4}$, Denise Beckles ${ }^{4}$, Philippe Schmitt-Kopplin ${ }^{5,6}$, 5 Mourad Harir ${ }^{5,6}$, Beate Schneider ${ }^{2 \#}$, Christine Stumpp ${ }^{7,8}$, and Dirk Wagner,9

6

7

Affiliations

$8{ }^{1}$ Astrobiology Group, Center for Astronomy and Astrophysics, Technische Universität Berlin, 9 Hardenbergstr. 36, 10623 Berlin, Germany

$10{ }^{2}$ GFZ German Research Centre for Geosciences, 14473 Potsdam, Germany

$11{ }^{3}$ Department of Experimental Limnology, Leibniz Institute of Groundwater Ecology and Inland 12 Fisheries (IGB), 16775 Stechlin, Germany

$13{ }^{4}$ University of The West Indies, St. Augustine, Trinidad and Tobago

$14{ }^{5}$ Research Unit Analytical Biogeochemistry, Department of Environmental Sciences, Helmholtz

15 Zentrum München, Ingolstädter Landstrasse 1, D-85764 Neuherberg, Germany

$16{ }^{6}$ Analytical Food Chemistry, Technische Universität München, Maximus-von-Imhof-Forum 2, 85354

17 Freising, Germany

$18{ }^{7}$ Institute of Groundwater Ecology, Helmholtz Zentrum München, 85764 Neuherberg, Germany

$19{ }^{8}$ Institute for Soil Physics and Rural Water Management, University of Natural Resources and Life 20 Sciences Vienna, 1190 Wien, Austria.

$21{ }^{9}$ University of Potsdam, Institute of Geosciences, 14476 Potsdam, Germany

\# present affiliation: Federal Institute for Materials Research and Testing (BAM), 12205 Berlin, Germany

Corresponding Author: Dirk Schulze-Makuch, schulze-makuch@tu-berlin.de, tel: +49-30- 
Abstract

Terrestrial mud volcanoes are unique structures driven by tectonic pressure and fluids from the deep subsurface. These structures are mainly found in active tectonic zones, such as the area near the Los Bajos Fault in Trinidad. Here we report a chemical and microbiological characterization of three mud volcanoes, which included analyses of multiple liquid and solid samples from the mud volcanoes. Our study confirms previous suggestions that at least some of the mud volcano fluids are a mixture of deeper salt-rich water and surficial/precipitation water. No apparent water quality differences were found between sampling sites north and south of a major geological fault line. Microbiological analyses revealed diverse communities, both aerobic and anaerobic, including sulfate reducers, methanogens, carbon dioxide fixing and denitrifying bacteria. Several identified species were halophilic and likely derived from the deeper salt-rich subsurface water, while we also cultivated pathogenic species from the Vibrionaceae, Enterobacteriaceae, Shewanellaceae, and Clostridiaceae. These microorganisms were likely introduced into the mud volcano fluids both from surface water or shallow ground-water, and perhaps to a more minor degree by rain water. The identified pathogens are a major health concern that needs to be addressed.

Keywords: isotope, metabolomics, contamination, pathogens, mud volcanoes, fluids

Highlights.

- Mud volcano liquids from Trinidad are a mixture of deep-rooted water and surficial water

- The mixture of water from various reservoirs has a distinct chemical and microbial composition

- All samples collected from the mud volcanoes contain pathogens and mostly human pathogens, inferred to be introduced by surficial water

- Pathogens were also detected in rainwater, but only plant pathogens were confirmed.

\section{INTRODUCTION}


75 Mud volcanoes can typically be found along fracture or fault zones that are associated with

76 subduction zones (Dimitrov, 2002; Kopf, 2002; Kioka and Ashi, 2015). Fluids interact with

77 the host rock in the subsurface and then protrude as mud slurries onto Earth's surface. The environmental impact of mud volcanoes has often been a research focus. The studies tend to investigate three main topics: (i) the impact of the mud and its components on aquatic and terrestrial environments (Plumlee et al., 2008), and (ii) mud volcanoes as a greenhouse gas source, due to methane and carbon dioxide emissions (Sauter et al., 2006), and (iii) microbial organisms associated with the mud slurries (Yakimov et al., 2002; Martinez et al., 2006, Niemann et al. 2006). Mud volcanoes are also used as a window into the deep subsurface biosphere. In some instances, the mud has been shown to have elevated concentrations of trace metals such as arsenic (Liu et al., 2009, 2011, 2013), aluminum, manganese (Bonnano et al., 2012) and mercury (Mieiro et al., 2017). The introduction of the mud itself into waterways increases suspended sediment levels and turbidity and may increase dissolved organic matter resulting in low dissolved oxygen levels, impacting aquatic life (Jennerjahn et al., 2013). Mud volcanoes are also well known for their gas emissions, which includes mostly the greenhouse gas methane, but also carbon dioxide. The contribution of mud volcanoes to the greenhouse gas inventory might be significant, yet it has not traditionally been considered (Chao et al., 2010; Milkov et al., 2003; Kokh et al. 2017).

In addition to these more well-known environmental issues surrounding mud volcano emissions, there is also the consideration of direct human health impact due to the presence of human pathogens in the mud. While it is not likely that the hot ejecta itself would be a source 97 of such organisms (Lösekann et al., 2007), the nutrients in the mud may result in increased microbial growth (Plumlee et al. 2008), and hence a possible increased risk for also finding pathogens. In addition, the mud may mix with rain water, which can be a possible source of pathogens as well. There are a few studies that report pathogen contamination from rainwater 
101 in the Caribbean; most investigated fecal and total coliform taxa in rainwater harvesting 102 systems (Welch et al. 2000; Peters 2011; Saunders et al. 2003). In the Grenadines study 103 (Welch et al 2000) rainwater was found to have no fecal coliform, but did have low counts of 104 total coliform. In all of the Caribbean studies, stored rainwater (barrels, tanks or cisterns) was 105 found to be contaminated with fecal or total coliform, in some instances, at levels high 106 enough to be hazardous. While the detected contamination could also be derived from the 107 contamination of the tanks, other studies found that rainwater can have significant levels of 108 active bacteria (Cho and Jang, 2014; Hu et al. 2017; Kaushik et al. 2014), and could be a 109 mechanism for the transport of pathogens for both humans (Kaushik et al. 2012; Evans et al. 2006) and plants (Constantinidou et al 1990). This study builds upon the previous studies by

111 identifying types of bacterial species present in the mud volcano effluents, both liquid and 112 solid, identifying the sources of the water and potential biogeochemical processes within the 113 different mud volcanoes.

The mud volcanoes selected for this study are located in Trinidad and have been characterized according to their fluid chemistry and variable periods of activity by the seminal papers of 117 Dia et al. (1999) and Deville and Guerlais (2009), respectively. The authors claimed that the 118 mud volcano fluids can be distinguished on the island of Trinidad into two groups based on 119 their chemical and isotopic composition, and that these two groups are geographically divided 120 by a major right lateral wrench fault, the Los Bajos fault line, which also acts as a major 121 drain. Our study had the initial objective to determine whether there was also a difference in 122 microbial composition between locations north and south of the fault line. Thus, we selected 123 two sites located northeast (Digity and Devil's Woodyard) and one site southwest (Balka 124 Devi) of the Los Bajos fault (Figure 1). Only later we discovered that the mud volcano fluids had significant pathogen loads, which led to a re-focussing of the undertaken study. 


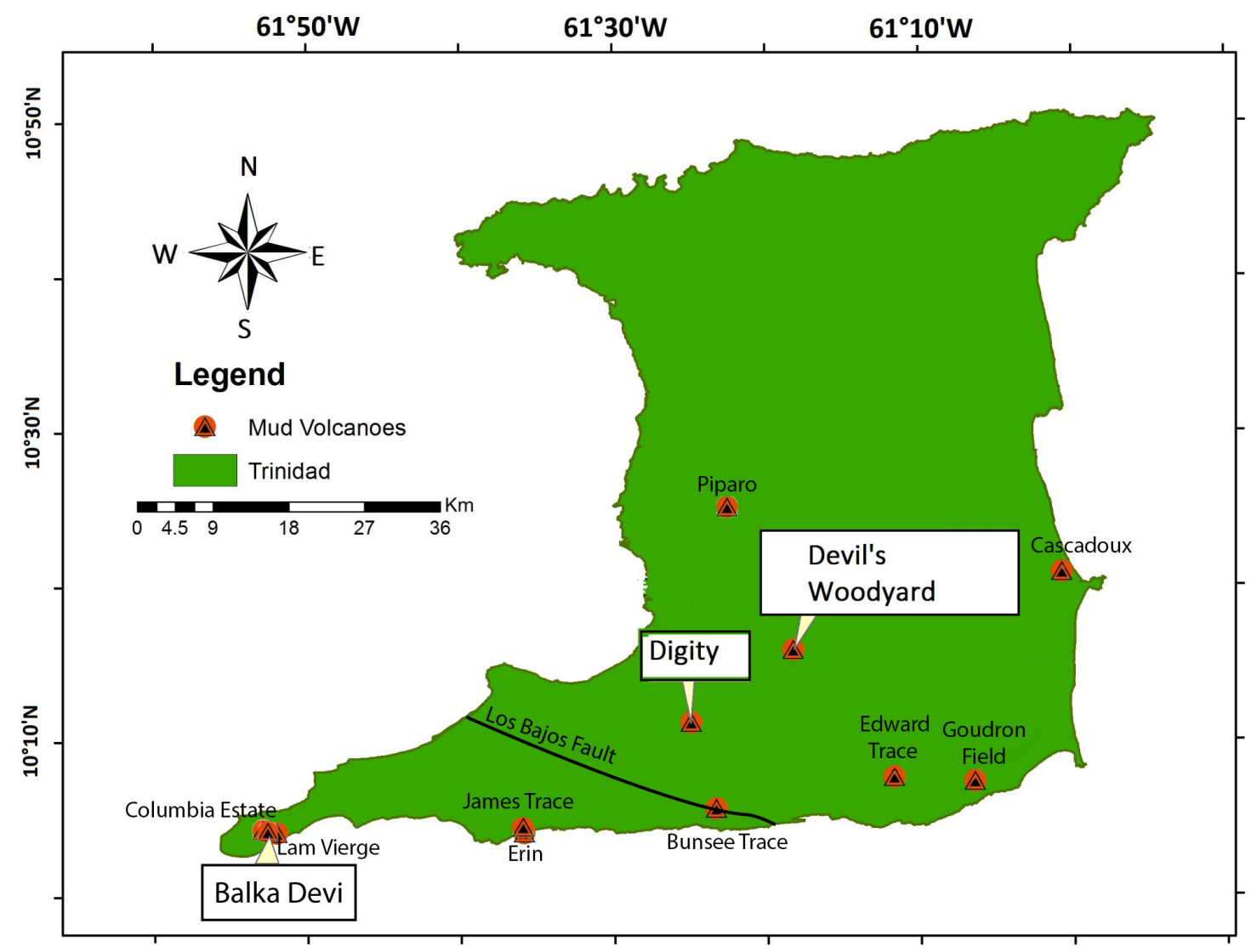

Figure 1. Sampling locations of selected mud volcanoes in Trinidad. Devil's Woodyard, Digity and Balka Devi were sampled.

\section{MATERIALS AND METHODS}

\subsection{Study Sites}

The mud volcanoes in Trinidad belong to a several hundred kilometers-long active belt of active sediment mobilization processes, which occur in the convergent orogen between the Caribbean and the South American plate and are characterized by cyclic phases of activity, ranging from periods of relative quiescence to events of catastrophic magnitude (Deville and Guerlais, 2009; Sundar and Darsan, 2019). Based on elemental, isotopic, and mineralogical analyses, Dia et al. (1999) determined that the fluids from the Trinidad mud volcanoes were originally oceanic, from a reservoir at a depth of more than $3 \mathrm{~km}$ within Miocene sediments,

141 but that their chemical composition changed due to high temperature fluid-rock interactions. 
143 The selected sample locations were described during the field visit as to their environmental

144 setting and observed fluids (Figures 1 and 2; Table 1). Devils Woodyard was eruptively active

145 and sampled at two locations, one at the surface (DW-1-0), the other at the surface (DW-2-0)

146 and at a depth of $100 \mathrm{~cm}$ (DW-2-100). The mud volcano Digity was quiescent during the field

147 season in 2016 and sampled at a depth of $5 \mathrm{~cm}$ (Di-5); however, 50 meters from the cone an

148 active location was found in a streambed, which was sampled at the surface (Di-b-0). Finally,

149 three samples were taken from an active site at Balka Devi in close proximity, at the surface

150 (BD-0-L) and at depths from 0-5 cm (BD-0-5-S, BD-0-5-T, see Table 1 for details). All

151 samples were taken using latex gloves and collected in sterilized sampling containers. The

152 temperature of the recovered fluids was measured in the field, while basic chemical

153 parameters such as $\mathrm{pH}$, conductivity, main ions, and stable water isotopes were determined in

154 the laboratory using standard methods. The amount of total petroleum hydrocarbons and oil

155 and grease in the samples was determined in the laboratory.

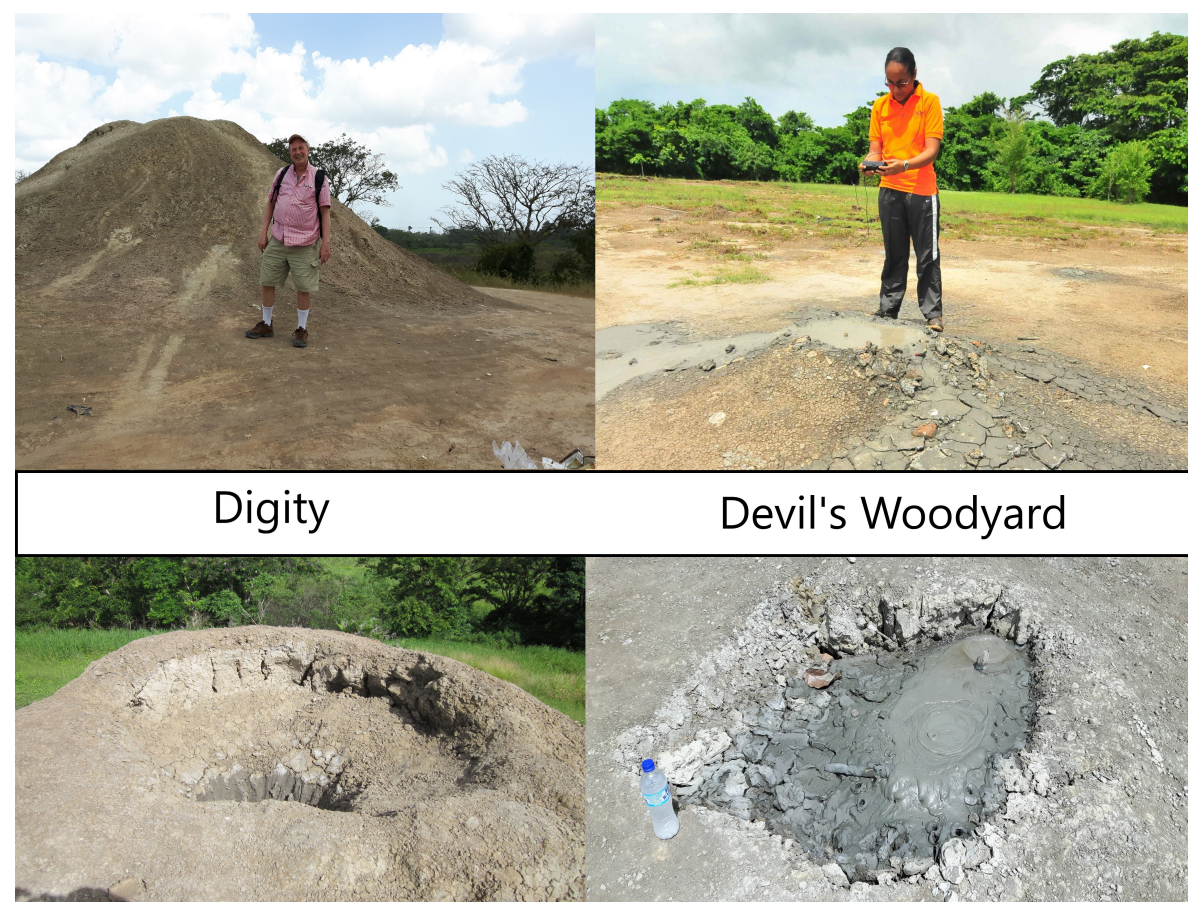

157 Figure 2. Photographs of the Digity mud volcano (sample Di-5 was taken $5 \mathrm{~cm}$ below the 158 cone of the mud volcano shown in the left image) and one of the mud volcanoes in the Devil's 159 Woodyard mud volcano field (DW 1). 
Table 1. Field observations of the collected samples. Devil's Woodyard (DW), Digity (Di), and Balka Devi (BD)

\begin{tabular}{|l|l|}
\hline Sample & Observation \\
\hline DW-1-0 & $\begin{array}{l}\text {-Soft Solid } \\
\text {-Dark brown in color on the outside, grey on the inside, } \mathrm{T}=30.5^{\circ} \mathrm{C}\end{array}$ \\
\hline DW-2-0 & $\begin{array}{l}\text {-Soft Solid } \\
\text {-Dark brown in color on the outside, grey on the inside, } \mathrm{T}=29.5^{\circ} \mathrm{C}\end{array}$ \\
\hline $\mathrm{DW}-2-$ & $\begin{array}{l}\text {-Soft Solid } \\
\text {-Dark brown in color on the outside, grey on the inside, } \mathrm{T}=29.5^{\circ} \mathrm{C}\end{array}$ \\
\hline Di-5 & $\begin{array}{l}\text {-Top of the mound, dug into the cone and sampled at a depth of } 5 \mathrm{~cm}, \text { moist mud, } \\
\text { but not active, hard solid mud } \\
\text { - Dark brown in color with white growth patches on surface of sample, possibly } \\
\text { fungal in origin }\end{array}$ \\
\hline Di-b-0 & $\begin{array}{l}\text {-About } 50 \mathrm{~m} \text { off the cone, active bubbling, very liquid, } \mathrm{T}=28.0^{\circ} \mathrm{C} \\
\text {-Medium brown in color } \\
\text {-Sandy texture }\end{array}$ \\
\hline BD-0-L & $\begin{array}{l}\text { - Very liquid, enclosed in dome-shaped mud structure, } \mathrm{T}=32.5^{\circ} \mathrm{C} \\
\text {-Medium to light brown in color } \\
\text {-Sandy texture }\end{array}$ \\
\hline BD-0-5- & $\begin{array}{l}\text {-Caked solid } \\
\text {-Sandy texture } \\
\text {-Medium to light brown color } \\
\text {-Sedimentation observed } \\
\text {-Cup holding sample was cracked allowing any liquid in sample to be lost }\end{array}$ \\
\hline $\begin{array}{l}\text { BD-0-5- } \\
\text { T }\end{array}$ & $\begin{array}{l}\text {-Soft Solid } \\
\text {-Dark brown in color } \\
\text {-Sedimentation observed }\end{array}$ \\
\hline
\end{tabular}

164

\subsection{Geochemical analysis}

As sample preparation, 5 grams of each sample were mixed with $30 \mathrm{ml}$ of deionized water to form a slurry, from which $\mathrm{pH}$, electrical conductivity, anions and cations were measured. $\mathrm{pH}-$ values and electrical conductivity were obtained with a $\mathrm{pH}$-meter and a conductivity meter, respectively. Chloride and nitrate were measured with reference electrodes and prepared standards. The cations were measured using a Block Digester and a FAA Spectrometer, by utilizing standard solutions.

Available phosphorus was determined by dissolving $0.40 \mathrm{~g}$ of ammonium molybdate and 0.01 $\mathrm{g}$ antimony potassium tartrate in $40 \mathrm{ml}$ of distilled water and diluted to $50 \mathrm{ml}$. Then $3.00 \mathrm{~g}$ of ascorbic acid was dissolved in $40 \mathrm{ml}$ of distilled water and diluted to $50 \mathrm{ml} .0 .10 \mathrm{ml}$ of 
177 acetone and $15.50 \mathrm{ml}$ of conc. $\mathrm{H}_{2} \mathrm{SO}_{4}$ were added. Approximately $1.0 \mathrm{~g}$ of each sample was

178 weighted in a beaker and $50 \mathrm{ml}$ of distilled water was added to each sample and stirred for 30 179 minutes. Then $0.01916 \mathrm{~g}$ of $\mathrm{KH}_{2} \mathrm{PO}_{4}$ was dissolved in $100 \mathrm{ml}$ of distilled water as standard 180 preparation. $1 \mathrm{ml}$ of this solution was diluted with $100 \mathrm{ml}$ with distilled water. $1 \mathrm{ml}$ of $11 \mathrm{~N}$ 181 sulphuric acid and $4 \mathrm{ml}$ of ammonium molybdate-antimony potassium tartrate were added to 182 each sample and standard, and mixed. $2 \mathrm{~mL}$ of ascorbic acid solution were added and mixed 183 in. After 5 minutes, the absorbance at $650 \mathrm{~nm}$ was measured with a spectrophotometer and the 184 phosphorus concentration was determined from the standard curve.

Chemical Oxidant Demand (COD) were measured by dissolving $1.02 \mathrm{~g}$ of potassium hydrogen phthalate, in $50 \mathrm{ml}$ of distilled water. This produced a $0.1 \mathrm{M}$ solution. Serial dilutions were made to produce solutions of $0.05,0.025$ and $0.0125 \mathrm{M}$ from the $0.1 \mathrm{M}$ solution. Then $2 \mathrm{ml}$ of sample or standard were added to the labelled tubes. Digestion was allowed in the COD reactor for 2 hours. Absorbance was read at a wavelength of $620 \mathrm{~nm}$.

The amount of total petroleum hydrocarbon was determined by dissolving the extract, which was obtained using US-EPA 1664 method in $50 \mathrm{ml}$ of hexane. $5 \mathrm{~g}$ of silica gel (60-200) was added and the mixture was filtered through filter paper containing anhydrous sodium sulphate. A rotary evaporator was used to reduce volume, and the remnants were dried in a $70^{\circ} \mathrm{C}$ oven for 2 hours and weighed. The mass of total petroleum hydrocarbons is the difference between the mass of the initial round bottom flask and the mass of the flask containing the extract.

200 U.S. EPA method 1664 was also used to determine total oil and grease. In brief, the $250 \mathrm{ml}$ 201 round bottom flask containing boiling chips was dried in the oven at $100^{\circ} \mathrm{C}$ for 1 hour, and 202 subsequently in the desiccator before weighing. A Soxhlet apparatus and $200 \mathrm{ml}$ of distilled 
203 hexane were used for further processing. The hexane was just allowed to boil and the

204 extraction was run for 6.5 hours. With a rotary evaporator the excess solvent was removed 205 reducing the volume of the extract. The flask containing the reduced extract was placed in a $20670^{\circ} \mathrm{C}$ oven for 2 hours, then allowed to cool in a desiccator. The weight was recorded. The 207 total oil and grease was the difference between the mass of the initial round bottom flask and 208 the mass of the flask containing the extract. All mud volcano samples were analyzed for these 209 basic chemical parameters except sample DW-2-0.

210

211

212

213

214

215

216

217

218

219

220

221

222

223

224

225

226

227 as $\delta$-value (\%o), which is the relative deviation of the sample from a standard $\left(R_{\text {standard }}\right)$ :

\subsection{Water stable isotope analysis}

Water stable isotope analysis was conducted in the mud volcano samples. In two out of seven samples (DW-2-100, BD-0-5-S) free water was available and filtered $(0.45 \mu \mathrm{m})$ before stable water isotope analysis. In the other samples, sediment pore water was extracted via cryogenic extraction for the analysis of stable water isotopes following common procedures (e.g. Königer et al. 2011; Orlowski et al. 2018). 6-15 g moist sediment was used depending on the expected water content $(0.18-0.40 \mathrm{~g} / \mathrm{g}$ gravimetric water content). Water was extracted at $105^{\circ} \mathrm{C}$, and the extraction was completed ( $\geq 99.3 \%$ efficiency) after $105-120 \mathrm{~min}$. The isotope ratios of the water $\left({ }^{18} \mathrm{O} /{ }^{16} \mathrm{O}\right.$ and $\left.{ }^{2} \mathrm{H} /{ }^{1} \mathrm{H}\right)$ were measured in $0.75-1.5 \mathrm{ml}$ water samples by cavity ring-down spectroscopy (Picarro L-2130i). A two-point calibration with laboratory reference material calibrated against VSMOW-SLAP (Vienna Standard Mean Ocean WaterStandard Light Antarctic Precipitation) scale was used. Each sample was measured up to nine times. Precision of the instrument $(1 \sigma)$ was better than $0.1 \%$ and $0.6 \%$ for $\delta^{18} \mathrm{O}$ and $\delta^{2} \mathrm{H}$, respectively. Values are reported as the ratio of isotopes $\left(R_{\text {sample }}\right)$, given in the delta notation

$$
\delta(\%)=\frac{R_{\text {Sample }}-R_{\text {Standard }}}{R_{\text {Standard }}} \cdot 1000
$$


Negative electrospray ionization Fourier transform ion cyclotron resonance [ESI(-)] FT-ICR mass spectra were acquired using a 12T Bruker Solarix mass spectrometer (Bruker Daltonics,

Bremen, Germany) and an Apollo II electrospray ionization (ESI) source in negative mode.

Pore water from mud volcanoes was processed (after acidification with formic acid) through solid-phase cartridges (Bond Elut PPL, $100 \mathrm{mg}, 1 \mathrm{ml}$, Agilent) to desalt them before 237 electrospray infusion, whereas sediments from mud volcanoes were extracted using toluene 238 solvent. Subsequently, an appropriate concentration of the SPE extracts were prepared in methanol while the toluene extracts were prepared in methanol/ammonium hydroxide for [ESI(-)] FT-ICR-MS analysis. Infusion of samples was done with a microliter pump at a flow 241 rate of $120 \mu \mathrm{h} \mathrm{h}^{-1}$ with a nebulizer gas pressure of $138 \mathrm{kPa}$ and a drying gas pressure of 103 $242 \mathrm{kPa}$. A source heater temperature of $200{ }^{\circ} \mathrm{C}$ was maintained to ensure rapid desolvation of the 243 ionized droplets. The spectra were acquired with a time domain of $4 \mathrm{MW}$ in [ESI(-)], and 500 244 scans were accumulated for each mass spectrum. All spectra were internally calibrated using 245 appropriate reference mass lists. Data processing was done using Compass Data Analysis 4.0 246 (Bruker, Bremen, Germany) and formula assignment was made by in-house made software 247 (NetCalc) (Tziotis et al. 2011). Molecular formula assignments were generated based on the 248 exact mass differences using NetCalc software (Tziotis et al. 2011). The assigned molecular 249 formulas were based on a restricted list of selected small molecular units with defined mass differences (Tziotis et al. 2011). Here, the compositional networks enabled assignment of 251 elemental formulas out of mass spectra and allowed alignments according to compositional 252 relationships. The final assigned molecular formulas were categorized into groups containing $253 \mathrm{CHO}, \mathrm{CHNO}, \mathrm{CHOS}$, and CHNOS molecular compositions, which were used to reconstruct 254 the group-selective mass spectra. Plots of the assigned molecular formulas retrieved from the FTICR-MS data sets were processed using van Krevelen plots (Schmitt-Kopplin et al. 2010, Handle et al. 2017). FT-ICRMS data were normalized by unit-variance scaling in order to 
257 adjust variances between the samples (Lucio, 2009). A hierarchical clustering approach was

258 performed on the normalized data (Hierarchical Clustering Explorer 3.5, Maryland, USA).

259 Calculation of clusters was done using average linkage and Euclidian metric as similarity

260 search. The process allows to group samples in a homogeneous and distinct cluster without

261 prior knowledge of data classification.

262

263

264

265

266

267

268

269 added at 1.5 atmospheres of overpressure.

\section{Media and cultivation}

\subsection{Microbiological Analyses}

For the cultivation of aerobic and anaerobic bacteria, TSA (trypticase soy agar, 1/10 strength) was amended with the following salts (per liter): $24.5 \mathrm{~g} \mathrm{NaCl}, 1 \mathrm{~g} \mathrm{CaCl}_{2}, 0.74 \mathrm{~g} \mathrm{KCl}, 2.43 \mathrm{~g}$ $\mathrm{MgCl}_{2}, 6.9 \mathrm{~g} \mathrm{MgSO}_{4}$. The $\mathrm{pH}$ value was adjusted to $7.8-8.0$ with $1 \mathrm{M} \mathrm{NaOH}$. To prevent the growth of fungi, cycloheximide (100 $\mathrm{g} \mathrm{ml}^{-1}$ final concentration) was added after autoclaving. For anaerobic growth the medium additionally contained $0.5 \mathrm{~g}$ sodium thioglycolate as a reducing agent and $0.001 \mathrm{~g}$ sodium resazurin as redox indicator. For preparation of the anaerobic medium the ingredients were dissolved in the medium with adjusted $\mathrm{pH}$ and afterwards the bottles were sealed with black rubber stoppers and a screw cap with a hole. The bottles were flushed with $\mathrm{N}_{2}$ for at least 30 min, until the redox indicator (resazurin) turned colorless. The medium was autoclaved with a hypodermic needle placed in the rubber stopper as air valve. After autoclaving the needle was removed immediately. The medium was cooled to about $60^{\circ} \mathrm{C}$ and transferred into the anaerobic glove box, where cycloheximide was added and the plates were poured and dried. Serial dilutions (in $2 \% \mathrm{NaCl}$ ) of the samples were plated and incubated at $28^{\circ} \mathrm{C}$. For growth under anaerobic conditions all steps were carried out in the glove box and the plates were transferred to an anaerobic chamber which was flushed with a mixture of $\mathrm{N}_{2}[80 \%]$ and $\mathrm{CO}_{2}[20 \%]$ for 10 min. Finally, the gas mixture was 
DNA of purified isolates was extracted by a simple standard protocol (Jacobsen, 1995). A bacterial colony was suspended in $100 \mu 1$ destilled water in a $0.2 \mathrm{ml}$ reaction tube and was incubated for $10 \mathrm{~min}$ at $98^{\circ} \mathrm{C}$ in a heating block. After boiling the suspension was cooled on ice immediately and then centrifuged for $10 \mathrm{~min}, 6000 \mathrm{x} \mathrm{g}, 4^{\circ} \mathrm{C}$. The supernatant contained

291 the DNA. A partial sequence of the 16 S ribosomal RNA gene was amplified with the primers

292 27F and 907R. Sequencing was done by GATC (Konstanz, Germany).

293

\section{Isolation of total DNA from samples}

DNA was isolated in triplicates with the PowerSoil DNA kit (MO BIO Laboratories, USA) applying a modified protocol from Direito et al. (2012). In brief, $0.5 \mathrm{~g}$ of soil was weighed into the bead-beating tube from which the buffer was removed previously. Instead, to enhance DNA recovery from the soil matrix, cell lysis was done in a FastPrep cell disrupter in the presence of $1 \mathrm{ml}$ of $1 \mathrm{M}$ phosphate buffer, $\mathrm{pH} 8.0$ containing $15 \%$ ethanol and $60 \mu \mathrm{l}$ solution $\mathrm{C} 1$ from the kit. To complete the lysis the tube was incubated in a block heater at $80{ }^{\circ} \mathrm{C}$ for 40 min before the first centrifugation. All further steps followed the PowerSoil manual. DNA was eluted with prewarmed $\left(55^{\circ} \mathrm{C}\right)$ solution $\mathrm{C} 6$.

\section{Quantitative PCR analysis (qPCR)}

The qPCR was performed in a CFX Connect Real-Time PCR Detection System (Bio-Rad, CA, USA) in duplicates of total DNA extracted from the sediment samples using iTaq Universal SYBR Green Supermix (Bio-Rad). DNA was amplified with the universal primers $331 \mathrm{~F}$ and 797R (Nadkarni et al, 2002) and the following cycling parameters: initial denaturation at $95^{\circ} \mathrm{C}, 3 \mathrm{~min}$ followed by 40 cycles $\left(95^{\circ} \mathrm{C}, 30 \mathrm{~s} ; 58^{\circ} \mathrm{C}, 30 \mathrm{~s} ; 72^{\circ} \mathrm{C}, 30 \mathrm{~s} ; 80^{\circ} \mathrm{C}\right.$, 3 s plus plate read). The correlation coefficient for the standard curves was $\geq 0.99$ and the PCR efficiency was on average $90 \%$. The standard was a known concentration (copy numbers) of a 16S rRNA gene PCR fragment of Bacillus subtilis. To measure the abundances of functional 
315 genes DNA was amplified with primers targeting $c b b \mathrm{~L}$ (large subunit gene of ribulose-1,5-

316 bisphosphate carboxylase/oxygenase a marker of carbon dioxide fixing bacteria), $d s r \mathrm{~B}$

317 (dissimilatory sulfite-reductase beta subunit gene a marker of sulfate-reducing bacteria), $m c r \mathrm{~A}$

318 (alpha subunit gene of methyl coenzyme M reductase a marker of methanogens also a proxy

319 for Archaea), and nirS (nitrite reductase gene from denitrifying bacteria). The corresponding

320 primers and cycling parameters were: cbbLR1F/ cbbLR1intR (Selesi et al., 2005, 2007),

321 initial denaturation at $95^{\circ} \mathrm{C}, 3$ min followed by 40 cycles $\left(95^{\circ} \mathrm{C}, 15 \mathrm{~s} ; 60^{\circ} \mathrm{C}, 1 \mathrm{~min} ; 80^{\circ} \mathrm{C}, 3 \mathrm{~s}\right.$

322 plus plate read), the standard was a known concentration of the $c b b \mathrm{~L}$ gene fragment of

323 Xanthobacter autotrophicus; dsr2060F/dsr4R (Geets et al., 2006), initial denaturation at $95^{\circ} \mathrm{C}$,

3243 min followed by 40 cycles $\left(95^{\circ} \mathrm{C}, 5 \mathrm{~s} ; 60^{\circ} \mathrm{C}, 30 \mathrm{~s} ; 72^{\circ} \mathrm{C} 10 \mathrm{~s} ; 80^{\circ} \mathrm{C}, 3 \mathrm{~s}\right.$ plus plate read), the

325 standard was a known concentration of the $d s r \mathrm{~B}$ gene fragment of Desulfovibrio vulgaris;

$326 \mathrm{mlasF} / \mathrm{mcrAR}$ (Steinberg \& Regan, 2008), initial denaturation at $95^{\circ} \mathrm{C}, 3 \mathrm{~min}$ followed by 40

327 cycles $\left(95^{\circ} \mathrm{C}, 5 \mathrm{~s} ; 60^{\circ} \mathrm{C}, 20 \mathrm{~s} ; 72^{\circ} \mathrm{C} 30 \mathrm{~s} ; 80^{\circ} \mathrm{C}, 3 \mathrm{~s}\right.$ plus plate read), the standard was a known

328 concentration of the mcrA gene fragment of Methanosarcina barkeri; nirSnF/nirSnR (Smith

329 et al., 2007), initial denaturation at $95^{\circ} \mathrm{C}, 3 \mathrm{~min}$ followed by 40 cycles $\left(95^{\circ} \mathrm{C}, 15 \mathrm{~s} ; 60^{\circ} \mathrm{C}, 1\right.$

$330 \mathrm{~min} ; 80^{\circ} \mathrm{C}, 3 \mathrm{~s}$ plus plate read), the standard was a known concentration of the nirS gene

331 fragment of Pseudomonas sp.

\section{Phospholipid Fatty Acid (PLFA) Analyses}

PLFAs are a main component of the membranes of all microbes and were analyzed using the modified Bligh and Dyer method, as described by Smith et al. (1986). PLFAs decompose 337 quickly upon cell death, thus are thought to represent all viable cells in an environmental

338 sample. Some organisms produce specific or signature types of PLFA biomarkers allowing 339 quantification of important microbial functional groups (e.g. iron reducers, sulfate reducers, 340 or fermenters). The relative proportions of these groups of PLFA biomarkers provide a 341 fingerprint of the microbial community (White et al., 1998; Schulze-Makuch et al., 2003). 
342 Terminally-branched saturated PLFA are generally characteristic for Gram-positive bacteria,

343 but also occur in cell membranes of sulfate-reducing bacteria. Monoenoic PLFA occurs in

344 Gram negative bacteria, particularly in those that are fast growing, utilize many carbon

345 sources, and adapt quickly to a variety of environments. Branched monoenoic PLFA is

346 common in obligate anaerobic bacteria, such as sulfate or iron-reducing bacteria. Mid-chain

347 branched saturated PLFAs are typical for Actinomycete spp., certain Gram-positive bacteria

348 and sulfate-reducing bacteria. Normal saturated PLFAs commonly occur in less-diverse 349 microbial populations, but provide very little information about their phylogenetic affiliation.

350 Polyenoic PLFA is characteristic for eukaryotic microorganisms.

\section{RESULTS}

353

\subsection{Basic chemical and isotopic analyses}

355 The $\mathrm{pH}$ was alkaline for all mud volcano fluids analyzed independent of the location (Table

2). Nitrate values were particularly high for Di-b-0, which would be consistent with some anthropogenic contamination.

Table 2: $\mathrm{pH}$, conductivity, and main ions

360

\begin{tabular}{|l|l|l|l|l|l|l|}
\hline Sample & $\mathrm{pH}$ & $\begin{array}{l}\text { Electric } \\
\text { Conductivity } \\
(\mathrm{mS} / \mathrm{m})\end{array}$ & $\begin{array}{l}\text { Nitrate } \\
(\mathrm{mM})\end{array}$ & $\begin{array}{l}\text { Chloride } \\
(\mathrm{mM})\end{array}$ & $\begin{array}{l}\mathrm{Na}^{+} \\
(\mathrm{mM})\end{array}$ & $\begin{array}{l}\mathrm{K}^{+} \\
(\mathrm{mM})\end{array}$ \\
\hline DW-1-0 & 9.01 & 2.88 & 1.7 & 23.8 & 55.5 & 70.8 \\
\hline DW-2-100 & 9.05 & 2.84 & 0.5 & 49.4 & 56.8 & 43.9 \\
\hline Di-5 & 9.55 & 1.94 & 1.1 & 23.8 & 50.9 & 44.3 \\
\hline Di-b-0 & 9.00 & 3.11 & 30.4 & 23.1 & 40.0 & 14.8 \\
\hline BD-0-L & 8.80 & 3.34 & 1.6 & 18.5 & 40.8 & 29.3 \\
\hline BD-0-5-S & 9.23 & 5.90 & 3.2 & 44.9 & 57.2 & 65.1 \\
\hline BD-0-5-T & 9.70 & 2.98 & 0.9 & 47.9 & 57.1 & 58.0 \\
\hline
\end{tabular}

The analyses of organic compounds indicated that all the fluids sampled included

363 hydrocarbons (Table 3), which is consistent with earlier findings by Meckenstock et al.

364 (2014) and indicative that the fluids transverse hydrocarbon-rich areas in the deeper 
365 subsurface. The amount of available phosphorus was consistent within all samples with a

366 value of about $0.7 \mathrm{mg} / \mathrm{l}$.

Table 3: Organic Carbon Analyses

\begin{tabular}{|l|l|l|l|l|l|}
\hline Sample & $\begin{array}{l}\text { Available } \\
\text { Phosphorus* } \\
(\mathrm{mg} / \mathrm{l})\end{array}$ & $\begin{array}{l}\text { COD }(\mathrm{mg}) \\
\mathrm{O}_{2}(\mathrm{mg})\end{array}$ & $\begin{array}{l}\text { Mass of Total } \\
\text { Petroleum } \\
\text { Hydrocarbon } \\
(\mathrm{g})\end{array}$ & $\begin{array}{l}\text { Mass of } \\
\text { Total Oil } \\
\text { and Grease } \\
(\mathrm{g})\end{array}$ & $\begin{array}{l}\text { Observation of } \\
\text { Extract from } \\
\text { Oil and Grease } \\
\text { Sample }\end{array}$ \\
\hline DW-1-0 & 0.7328 & N/A & 0.0002 & 0.0011 & Clear \\
\hline DW-2-100 & 0.7436 & N/A & 0.0003 & 0.0037 & Slight Yellow \\
\hline Di-5 & 0.6740 & N/A & 0.0004 & 0.0083 & Slight Yellow \\
\hline Di-b-0 & 0.7436 & 0.1083 & 0.0253 & 0.0480 & Very Yellow \\
\hline BD-0-L & 0.6610 & 0.4438 & 0.0004 & 0.0021 & Slight Yellow \\
\hline BD-0-5-S & 0.6610 & N/A & 0.0002 & 0.0011 & Clear \\
\hline BD-0-5-T & 0.6610 & N/A & 0.0005 & 0.0060 & Yellow \\
\hline
\end{tabular}

371 The majority of the samples had similar isotopic composition and clustered close together.

372 These isotopic values were in a similar range of values reported for the same mud volcanoes

373 in Trinidad (Dia et al. 1999) (Figure 3). Exceptions were the water extracted from the solid

374 sediment sample taken at Balka Devi (BD-0-5-S) with an exceptionally high $\delta^{18} \mathrm{O}$ value, and

375 the water sample at Digity (Di-b-0) (Table 4). The first (BD-0-5-S) was from a sample with

376 cracked cup and therefore, most likely fractionation processes resulted in large isotope ratios;

377 its initial value remains unknown. The latter (Di-b-0) plots close to an evaporation line

378 indicating surface or rain water as main source.

379

380

381

382
Table 4: $\delta^{18} \mathrm{O}$ and $\delta^{2} \mathrm{H}( \pm$ standard deviation) of water samples from mud volcanoes

\begin{tabular}{|l|l|l|}
\hline Sample & $\delta^{\mathbf{1 8}} \mathbf{O}(\%)$ & $\delta^{2} \mathbf{H}(\%)$ \\
\hline DW-1-0 & $3.54( \pm 0.04)$ & $-14.3( \pm 0.2)$ \\
\hline DW-2-0 & $3.77( \pm 0.04)$ & $-9.4( \pm 0.1)$ \\
\hline DW-2-100 & n.a. & n.a. \\
\hline Di-5 & $3.03( \pm 0.04)$ & $-1.2( \pm 0.3)$ \\
\hline Di-b-0 & $4.00( \pm 0.06)$ & $19.8( \pm 0.1)$ \\
\hline BD-0-L & $4.37( \pm 0.02)$ & $-1.3( \pm 0.3)$ \\
\hline BD-0-5-S & $10.89( \pm 0.07)$ & $20.0( \pm 0.1)$ \\
\hline
\end{tabular}




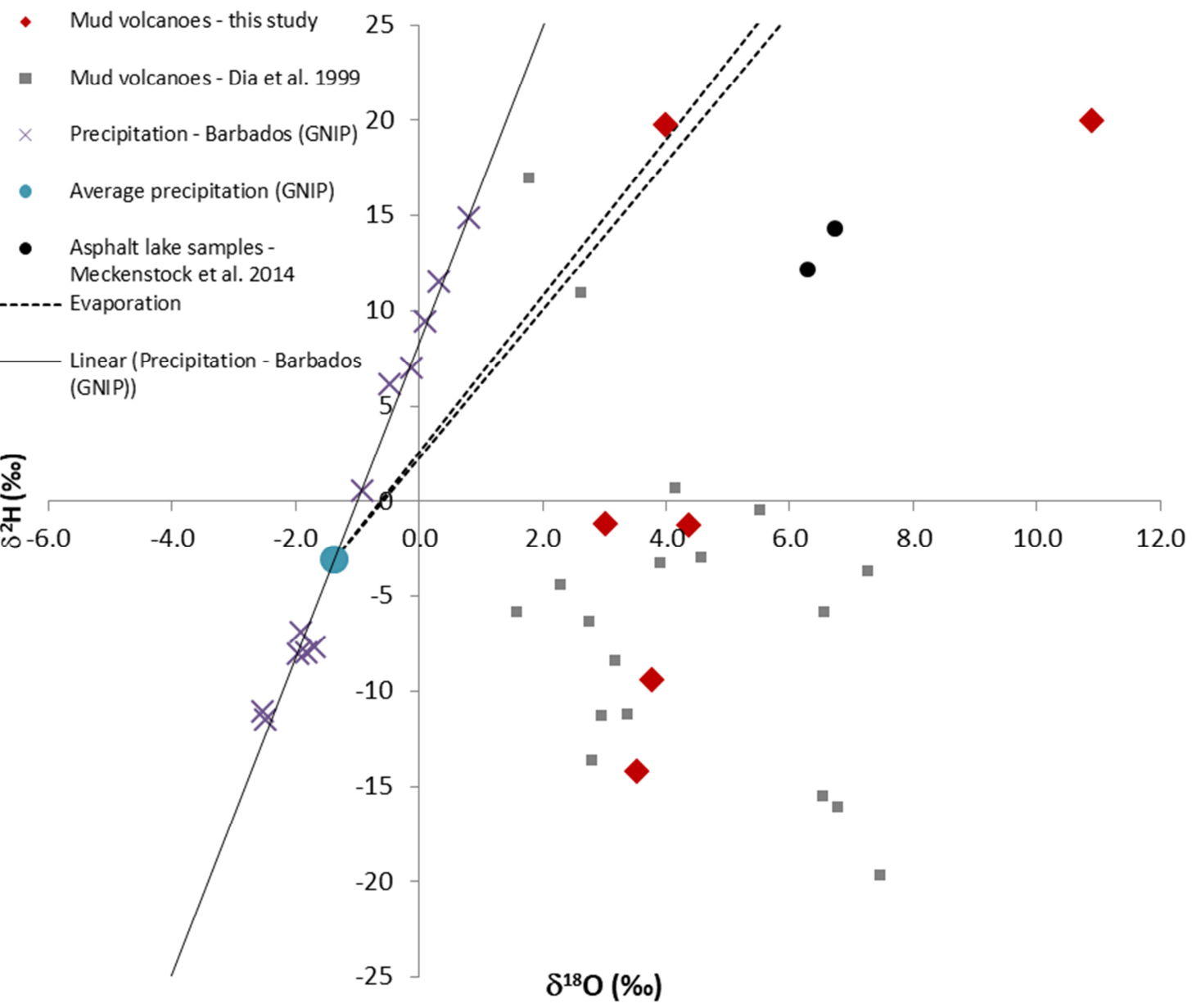

Figure 3: $\delta^{18} \mathrm{O}$ and $\delta^{2} \mathrm{H}$ of water samples from mud volcanoes (red symbols) in comparison to published data of monthly (purple crosses) and annual averages (blue circle) in precipitation from the closest station of the Global Network of Isotopes in Precipitation (GNIP) database of the International Atomic Energy Agency (IAEA) in Barbados (including the Local Meteoric Water line; black line), other mud volcanoes (grey squares; Dia et al. 1999) and asphalt lake samples (black circles; Meckenstock et al. 2014) from Trinidad. The estimated local evaporation line and its uncertainty range is depicted by the gray dashed lines (Meckenstock et al. 2014).

\subsection{Chemical Diversity Characteristics}

We examined the water extract of the mud volcano samples, representative of bioavailable and dynamic organic fraction and the toluene extracts more representative of the original organic geochemical signature of the mud-systems. All FTICR-MS spectra were extremely rich in the $\mathrm{C}, \mathrm{H}, \mathrm{N}, \mathrm{O}, \mathrm{S}$ compositional space and were close to the signature of oxidized asphalts (Figure S1). The van Krevelen diagrams (Figure S1) of toluene extracts showed smooth and widespread distributions over large ranges of unsaturation $(\mathrm{H} / \mathrm{C}$ ratio), down to 
404 low degrees of oxygenation (small O/C ratio). In contrast, water extracts showed an increase 405 in $\mathrm{O} / \mathrm{C}$ ratio (i.e. oxidation) with almost unchanged average hydrogen deficit except for Di-b4060 (Figure S1 and Table S1). CHO and CHNO molecular compositions were abundant in both 407 mud volcanoes extracts. However, $\mathrm{CHNO}$ and $\mathrm{CHOS}$ compounds were specifically 408 significant in Di-b-0, suggesting its unique individual chemical diversity of N,S409 functionalized compounds (Table S1, Figure S2). When sorted according to the number of 410 oxygen atoms in assigned $\mathrm{CHO}, \mathrm{CHNO}$ and $\mathrm{CHOS}$ molecular compositions, water extracts 411 showed a near Gaussian distribution as compared to toluene extracts (Figure S2). Thus, sorted 412 oxygen atoms in Balka Devi (BD-0-5-S) and Digity (Di-5) water extracts demonstrated 413 overall congruence of considerable oxygenation, sulfurization and nitrogenation of organic 414 molecules (Figure 2S-B). In addition, hierarchical cluster analysis (HCA) based on the 415 FTICR-MS dataset revealed the specific chemical composition variances across all mud 416 volcano extracts. HCA-based analysis of toluene mud extracts reflects the mineral bond and 417 water insoluble organic compounds and clearly differentiate three main groups: (i) Devil's 418 Woodyard (DW-1-0, DW-2-0 and DW-2-100), (ii) Balka Devi (BD-0-L, BD-0-5-S) and 419 Digity (Di-5), and (iii) Digity (Di-b-0), respectively (Figure 4A). At this level of 420 classification, chemical diversity in toluene mud extracts varied according to the mud volcano 421 sites in the order of Devil's Woodyard $<$ Balka Devi $\sim$ Digity (Di-5) $<$ Digity (Di-b-0), and 422 the FTICR MS-based molecular compositions related to this classification are shown in van 423 Krevelen diagrams (Figures 4B-D). All samples from the Devil's Woodyard site show 424 specifically highly aromatic oxygenated and nitrogen rich $\mathrm{CHO}$ and $\mathrm{CHNO}$ compounds $(0.5 \leq$ $425 \mathrm{H} / \mathrm{C} \leq 1.3$ and $0.1 \leq \mathrm{O} / \mathrm{C} \leq 0.35$ ) with weighted average DBE value of 11 . While the 426 compositional space in Balka Devi and Digity (Di-5) sites are highly characteristic for only $427 \mathrm{CHO}$ saturated and oxygen rich compounds ( $\mathrm{H} / \mathrm{C}>1.6$ and $1 \leq \mathrm{H} / \mathrm{C} \leq 1.6)$, Digity (Di-b-0) 428 was covering low oxygen containing compounds over a wide range of saturated and 429 unsaturated molecular ratios $(0.56 \leq \mathrm{H} / \mathrm{C} \leq 2.33$ and $0.02 \leq \mathrm{O} / \mathrm{C} \leq 0.33)$, which is 
430 characteristic of asphalts (Meckenstock et al. 2014, Handle et al. 2017). In contrast, the water-

431 soluble fraction showed no possible classification to geography. As shown in Figure 5, Digity 432 (i.e., Di-b-0 and Di-5) and Balka Devi (BD-0-5-S) were highly variable in their compositional 433 space, suggesting specific biogeochemical processes. As exception, Balka Devi (BD-0-L)

434 grouped together with Devil's Woodyard. As shown in Figure 5A, four groups of CHO, $435 \mathrm{CHNO}$, CHOS and CHNOS compounds with molecular ratios $0.5 \leq \mathrm{H} / \mathrm{C} \leq 1.5$ and $0.04 \leq$ $\mathrm{O} / \mathrm{C} \leq 0.5,1.5 \leq \mathrm{H} / \mathrm{C} \leq 2.5$ were observed, suggesting mainly $\mathrm{O}, \mathrm{N}, \mathrm{S}-$ fused aromatic compounds as well as appearance of mostly aliphatic acid compounds and derivatives, respectively (Fig 5B). Unlike, Di-b-0 was essentially rich in linear aliphatic and aromatic compounds with mostly extensively suite of naphthenic acids and derivatives with branched, cyclic and aromatic compounds (Fig 5C) reflecting a biodegradation of the original asphalts.

441 In addition, Balka Devi (BD-0-5-S) and Digity (Di-5) showed specific and individual 442 chemical diversity of O,N,S-functionalized $\mathrm{CHO}, \mathrm{CHNO}$ and $\mathrm{CHOS}$ compounds (Fig 5D and

5E) more specific of oxygen rich terrestrial organic matter.
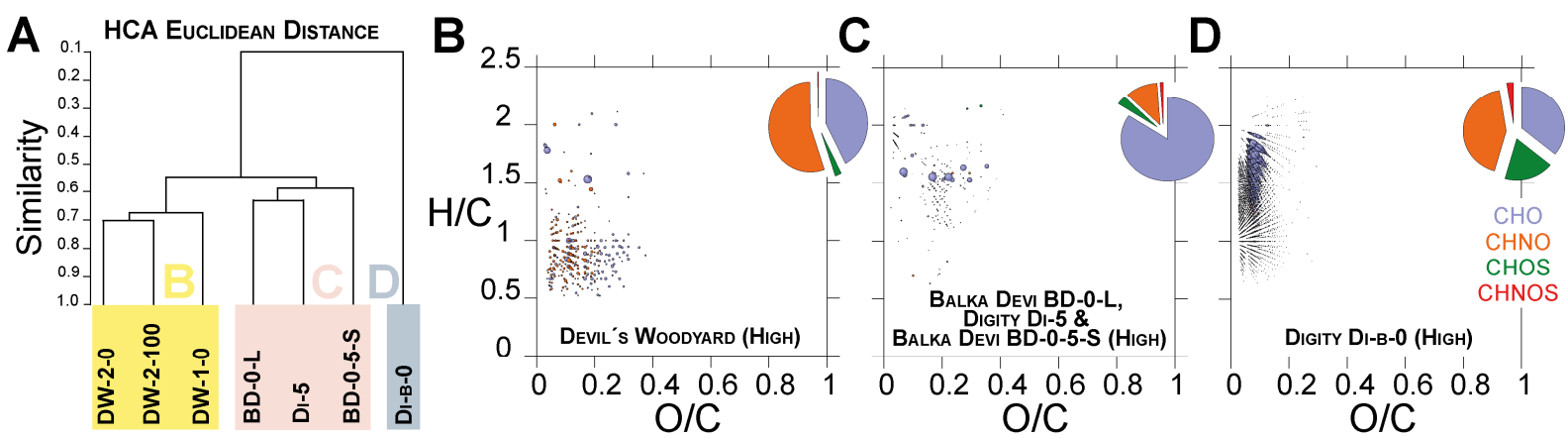

Figure 4. Negative electrospray 12T-FTICR mass data of toluene mud volcanoes sediments extracts. A Clustering diagram based on the similarity values between the spectra of the seven samples using Euclidean distance. B (Devil's Woodyard), C (Balka Devi, BD-0-L \& BD-0-5S, and Digity "Di-5"), and D (Digity "Di-b-0") show the van Krevelen diagrams of the most abundant mass peaks in each case respectively. Insert histograms represent the molecular series based on CHO (Blue), CHOS (green), CHNO (orange), and CHNOS (red) atom combinations. Bubble size is equivalent to mass peak intensity. 

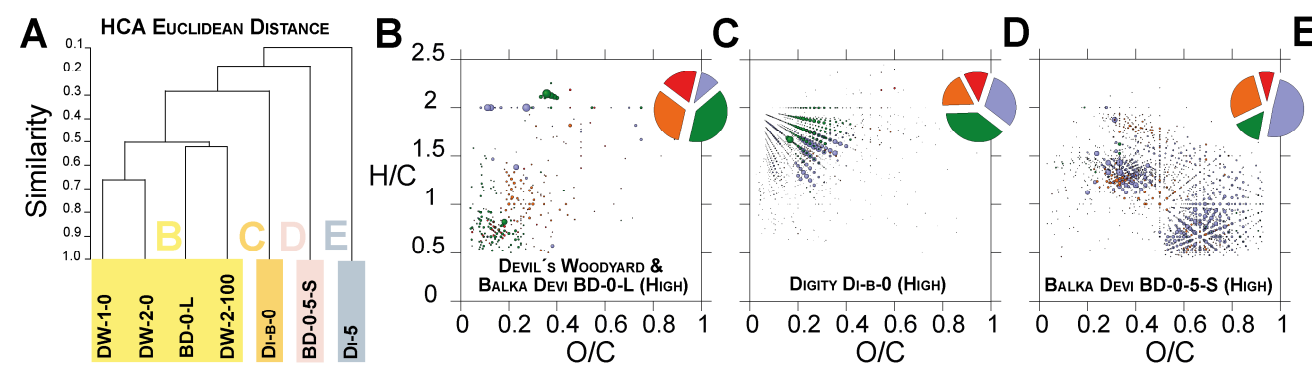

E

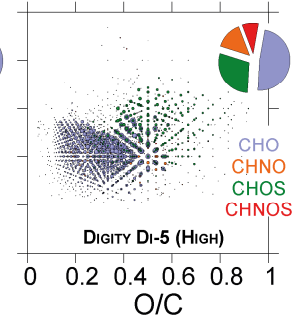

Figure 5. Negative electrospray 12 T FTICR mass data of water-soluble fractions of the mud volcano samples. A Clustering diagram based on the similarity values between the spectra of the seven samples using Euclidean distance. B (Devil's Woodyard and Balka Devi BD-0-L), C (Digity Di-b-0), D (Balka Devi BD-0-5-S) and E (Digity Di-5) show the van Krevelen diagrams of the most abundant mass peaks in each case respectively. Insert histograms represent the molecular series based on $\mathrm{CHO}$ (Blue), CHOS (green), CHNO (orange), and

\subsection{Microbiological Characterization}

The microbiological analysis consisted of phospholipid fatty acid (PLFA) analyses, culturing, and DNA sequencing. Biomass was also determined via PLFA analyses and revealed that the biomass was the lowest at Devil's Woodyard with biomass amounts at or below the detection limit of $10^{5}$ cells $\mathrm{g}^{-1}$, while biomass was by about a factor of 100 higher at the other mud volcano sites. Also, there was a much less diverse population at Devil's Woodyard than at

471 Digity and Balka Devi (Table 5). Low biomass and low diversity would generally be consistent with a higher contribution from deep-seated ground water, while a high biomass and diversity would be consistent with surface water or at least mixing with surface water.

474 The sample PAX is collected rain water and provided information on the biomass and microbial diversity of Trinidadian precipitation. The sample Di-5 was sampled $5 \mathrm{~cm}$ below the cavity mound of the Digity mud volcano (Fig. 2b), which did not seem to be active at the

477 time of sampling.

Table 5. Phospholipid fatty acid (PLFA) analyses

\begin{tabular}{|c|c|c|c|c|c|c|c|}
\hline Sample & $\begin{array}{l}\text { Biomass } \\
\text { (cells g- } \\
\text { or } \mathrm{mL}^{-1} \text { ) }\end{array}$ & $\begin{array}{l}\text { TerBrSats } \\
\text { (\% abund.) }\end{array}$ & $\begin{array}{l}\text { Monos } \\
\text { (\% abund.) }\end{array}$ & $\begin{array}{l}\text { BrMonos } \\
\text { (\% abund.) }\end{array}$ & $\begin{array}{l}\text { MidBrSats } \\
\text { (\% abund.) }\end{array}$ & $\begin{array}{l}\text { NSats } \\
\text { (\% abund.) }\end{array}$ & $\begin{array}{l}\text { Polyenoics } \\
\text { (\% abund.) }\end{array}$ \\
\hline $\begin{array}{l}\text { DW-1- } \\
0\end{array}$ & $\begin{array}{r}<2.94 \times \\
10^{5}\end{array}$ & 0 & 0 & 0 & 0 & 0 & 0 \\
\hline
\end{tabular}




\begin{tabular}{|l|r|l|l|l|l|l|l|}
\hline $\begin{array}{l}\text { DW-2- } \\
0\end{array}$ & $\begin{array}{r}1.12 \times \\
10^{5}\end{array}$ & 0 & 0 & 0 & 0 & 72.94 & 27.06 \\
\hline $\begin{array}{l}\text { DW-2- } \\
100\end{array}$ & $\begin{array}{r}8.82 \times \\
10^{5}\end{array}$ & 14.50 & 26.62 & 0 & 0 & 38.89 & 19.99 \\
\hline Di-5 & $1.2 \times 10^{7}$ & 18.88 & 43.80 & 1.54 & 9.50 & 24.73 & 1.56 \\
\hline Di-b-0 & $5.3 \times 10^{7}$ & 13.5 & 48.84 & 4.54 & 3.73 & 23.71 & 5.68 \\
\hline BD-0-L & $1.1 \times 10^{7}$ & 3.73 & 62.16 & 0 & 0.43 & 33.07 & 0.59 \\
\hline $\begin{array}{l}\text { BD-0- } \\
5-S\end{array}$ & $7.3 \times 10^{7}$ & 16.23 & 50.36 & 1.40 & 2.02 & 27.33 & 2.64 \\
\hline PAX & $1.6 \times 10^{6}$ & 0 & 63.45 & 0 & 0 & 31.87 & 4.68 \\
\hline
\end{tabular}

482 Legend: TerBrSats (terminal branched saturated) PLFA characteristic for Firmicutes. Monos (monoic) 483 PLFA characteristic for Proteobacteria, BrMonos (branched monoic) PLFA characteristic for 484 aneorobic metal reducers, MidBrSats (mid-branched saturated) PLFA characteristic for sulfatereducing bacteria and Actinomycetes, NSats (normal saturated) PLFA characteristics for relative "primitive" bacterial biota, and polyenoic PLFA characteristic for eukaryotes. abund. = abundance.

489 only consider the fraction of the total bacteria in a sample that can be cultured in a laboratory environment and therefore is lower compared to PLFA analysis. This was also the case with

491 the mud volcano samples for which generally $1 \%$ could be cultured. However, one advantage

492 of culturing the bacteria was that it can be distinguished between aerobic and anaerobic

493 microorganisms. The amount of culturable bacteria, both under aerobic and anaerobic

494 conditions, is shown in Table 6 and Figure 6. The rain water sample (PAX) did not contain 495 any anaerobic bacteria, because these types of bacteria cannot survive long in an oxygenated 496 atmosphere. 


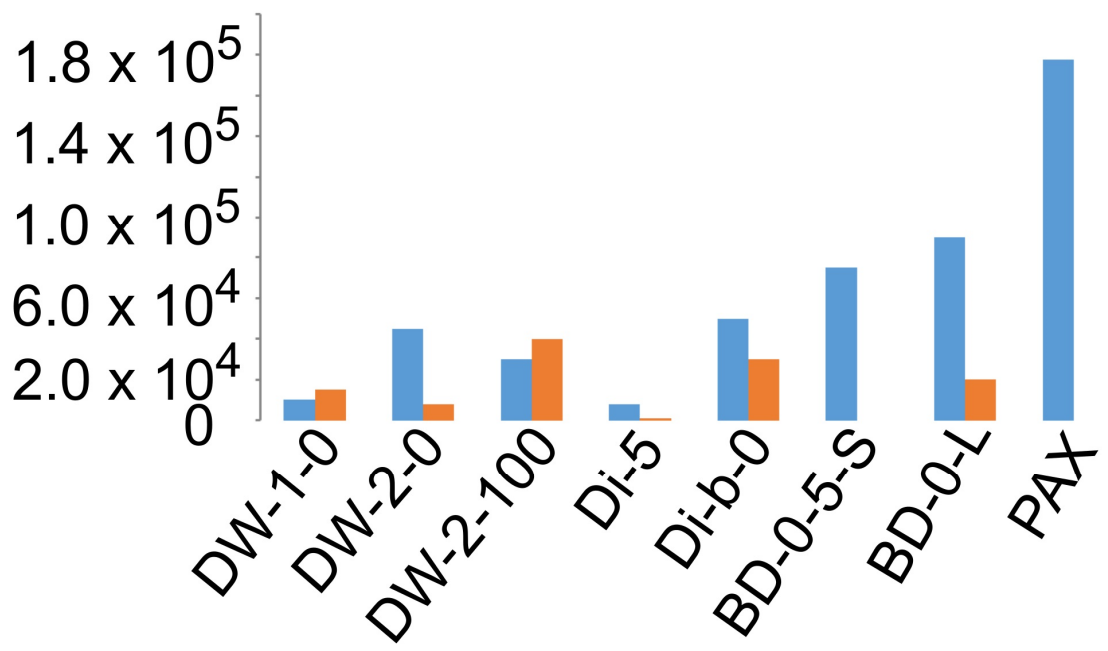

Figure 6. Aerobic vs anaerobic colony forming units (CFUs) per gram or $\mathrm{ml}$ of sample at sampling locations Devil's Woodyard DW, Digity Di, and Balka Devi BD.

qPCR analyses using the total DNA recovered, allowed us to detect and quantify functional genes which might be relevant to ecosystems that are anaerobic and influenced by the emission of gaseous compounds like methane and carbon dioxide (Dia et al., 1999). As typical anaerobic microorganisms in those environments we searched for sulfate reducing 510 bacteria, methanogenic archaea, and denitrifiers (Figure 7), and found that sulfate reducing 511 bacteria and methanogenic archaea were present at all sampling locations and depths. A high 512 potential of denitrifying bacteria was only detectable at DW-2 at a depth of $100 \mathrm{~cm}$ though 513 nitrate concentration was the lowest (Table 2). The high potential for $\mathrm{CO}_{2}$-fixing microbes in 514 the samples DW-2-100 and Di-5 might reflect higher $\mathrm{CO}_{2}$ concentrations. 


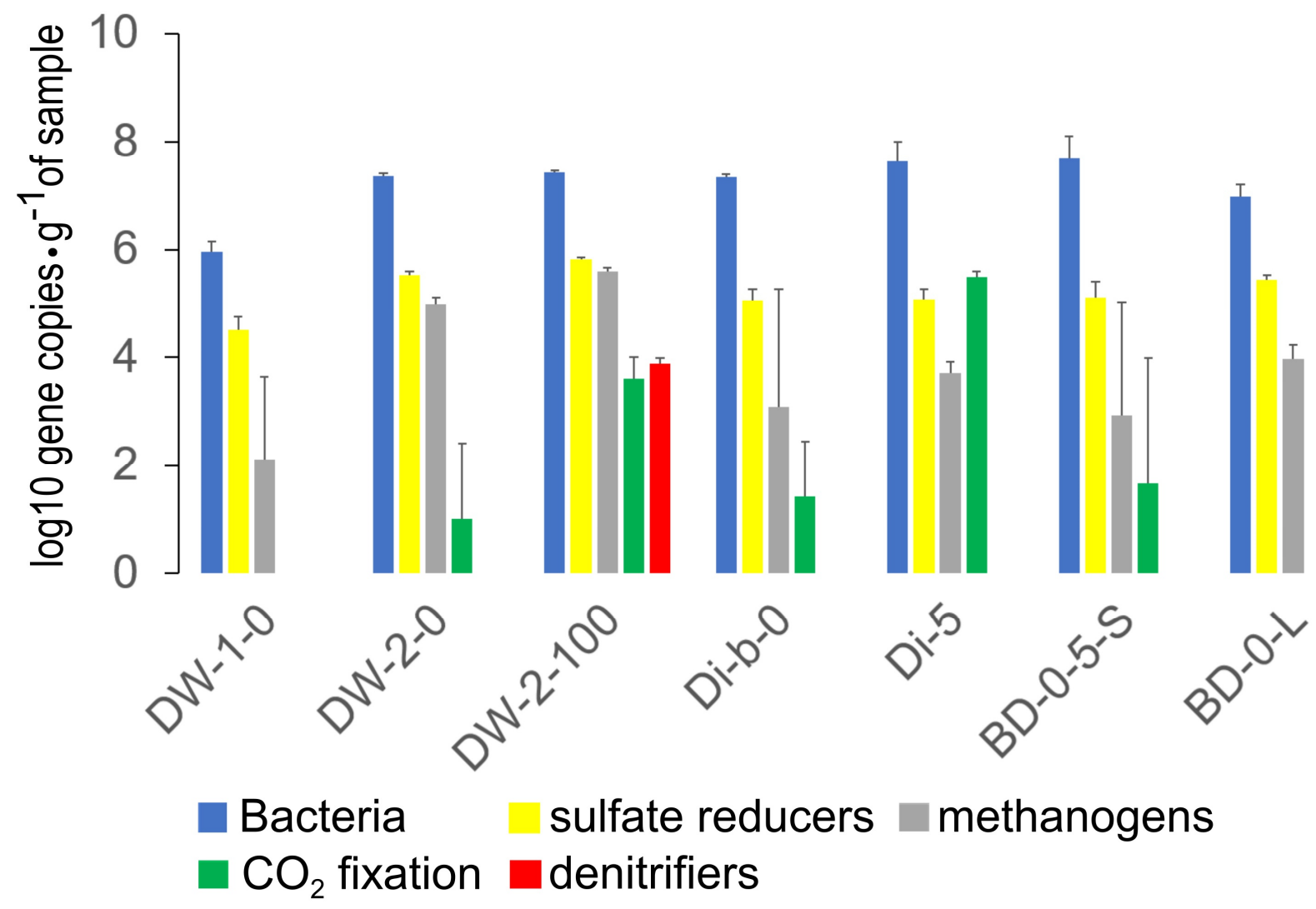

Figure 7. Microbial metabolic diversity within samples based on qPCR. Quantification based 520 on $16 \mathrm{~S}$ rRNA gene (universal bacteria), $d s r B$ gene (sulfate-reducers), $c b b L$ gene $\left(\mathrm{CO}_{2}\right.$

521 fixation), nir $S$ gene (denitrification), and $m c r A$ gene (methanogens)

The 16S rRNA gene analysis revealed further insights into the culturable microbial communities. We discovered several halophilic microorganisms but also many pathogenic strains. The likely pathogenic strains include members of the Enterobacteriaceae, Shewanellaceae, Clostridiaceae, and Vibrionaceae (Table 6). Interestingly, there appear to be also pathogenic microorganisms present in the rain water sample (PAX). Control samples collected near the DW and BD mud volcanoes revealed a very different microbial community not consisting of any of the pathogenic species detected in these mud volcano samples (e.g.,

531 including instead several Bacillus strains such as B. megaterium, B. aryabhattai, and B. cereus). 
536 Table 6. Species identification based on cultivation and followed up sequencing of cultured 537 cells. Cultivation was done on TSA (10\%) agar $+3.5 \%$ sea salts.

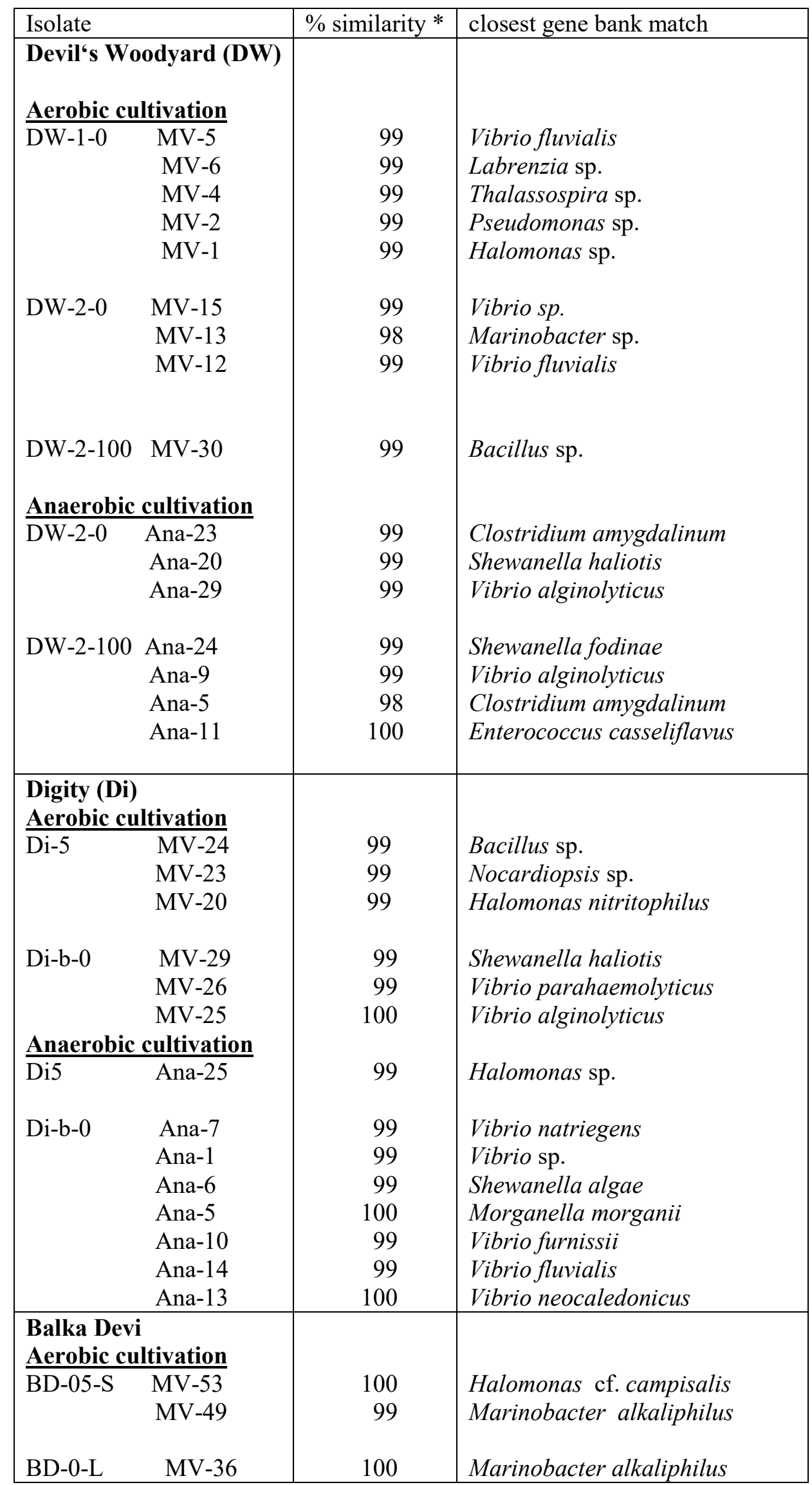




\begin{tabular}{|l|r|l|}
\multicolumn{1}{|c|}{ MV-32 } & 99 & Vibrio fluvialis \\
MV-38 & 99 & Rheinheimera sp. \\
Mitrincola sp. \\
Anaerobic cultivation & 98 & \\
\hline BD-0-L Ana-3 & 99 & Vibrio fluvialis \\
\hline PAX rain water & & \\
Aerobic cultivation & 99 & Pantoea ananatis \\
PAX-1 & 99 & Pantoea dispersa \\
PAX-2 & 99 & Klebsiella variicola \\
PAX-6 & 99 & Microbacterium sp. \\
PAX-12 & 100 & Enterobacter cloacae/E. ludwigii \\
PAX-13 &
\end{tabular}

\section{Discussion}

547 were reported previously for the same mud volcanoes in Trinidad (Dia et al. 1999) (Figure 3) 548 and also for other mud volcanoes worldwide as summarized by Mazzini \& Etiope (2017). Our

549 results confirm the findings by Dia et al. (1999) that the source area of the mud volcanoes in 550 Trinidad are deep seated seawater reservoirs, but also that a mixing occurs with water from 551 surface near aquifers (Dia et al. 1999). The samples from Devil's Woodyard indicate highest 552 contributions of deep water sources because these sample have the lowest $\delta^{2} \mathrm{H}$ (Figure 3) 553 plotting furthest from the local meteoric water line. The deep water source is also in 554 agreement with low biomass in these samples (Table 5). The water extracted from the solid 555 sample from Balka Devi (BD-0-S) is much higher in $\delta^{2} \mathrm{H}$ than expected; even higher 556 compared to samples from water droplets enclosed in the nearby pitch lake (Meckenstock et 557 al. 2014). These enriched values cannot be explained by uncertainties of the extraction 558 method (Orlowski et al. 2018), but could be the result of evaporative water loss during storage 559 (broken sampling cup). The sample from the inactive mud volcano (Di-b-0) has different 560 isotopic composition indicative of water with meteoric (rainwater) origin and evaporative 561 loss. Thus, water from surface water origin is the main source which most likely comes from 
562 a nearby river occasionally flooding this location. The different water source is supported by

563 the high biomass, the high nitrate and carbon content as well as the different chemical

564 diversity in Di-b-0 compared to other locations.

565

566 No grouping of chemical parameters is evident that would let us to conclude that the Los

567 Bajos Fault has a major role in water quality. This is in line with the analysis of the chemical

568 diversity characteristics that mainly impacted from the original asphalt organics (toluene 569 extract) and terrestrial runoff (water extract). Different types of clustering were apparent 570 according to the extraction protocols. Toluene mud sediment extracts showed that the

571 following three groups (1) DW 1-0, DW 2-0, DW 2-100, (2) Di-5, BD-0-5-S, BD-0-L, and

572 (3) Di-b-0 could be distinguished (Figure 4), while four groups could be distinguished in 573 water extracts (after SPE): (1) DW-1-0, DW 2-0, DW 2-100, BD-0-L, (2) Di-b-0, (3) BD-0-5-

574 S, and (4) Di-5 (Figure 5). The clustering of water extracts (after SPE) corresponds to the 575 grouping from isotope analysis.

577 The results from the microbial analyses were distinctly different compared to other mud 578 volcanoes outside of Trinidad (see below), but they conformed in principal to the grouping of 579 water based on chemical and isotopic indicators. There was a stark contrast between the 580 shallow locations at Devil's Woodyard (DW 1-0 and DW 2-0), where little biomass and 581 microbial diversity was encountered compared to the other sampling sites with a higher 582 biomass and diversity. This points to a deep water source, a hypothesis also supported by the 583 isotope analyses, which indicate a much higher contribution from water sources in the deep 584 subsurface compared to the other sites. However, even here a surface water component cannot 585 be excluded, because we do not know the isotopic composition of the end member (deep 586 water). Based on the PLFA data, the other samples have a much higher biomass and also a 587 rich diversity, which is typical for surface water environments. A revealing sampling location 
588 is Di-5, which is within the mound of the currently inactive Digity mud volcano. The sampled

589 microbial community resembles the community from the precipitation water sample mixed

590 within communities from the mud matrix, which is confirmed by the isotope analysis showing 591 that Di-5 has a larger contribution from rain water mixed with groundwater compared to the 592 samples from DW 1-0 and DW 2-0. First, it seems to be surprising that such a diverse and 593 rich community would be the result, but the precipitation data show that even in the rain water 594 there is a startling diverse and rich microbial community (although not as diverse as in Di-5).

595

596

\subsection{An unexpected microbial load}

598

599

Despite specific differences between the individual sampling locations, all our analyzed mud volcano samples contained sulfate reducing bacteria and methanogenic archaea (Fig. 7). They

600 are likely representative of the original fluids from the deep subsurface source before 601 exposure to shallow groundwater. These types of microbes were also found at the Haakon 602 Mosby Mud Volcano at the Barents Sea (Niemann et al., 2006, Lösekann et al., 2007). 603 Sulfate-reducing bacteria were also detected at a mud volcano site in southern Taiwan (Liu et 604 al., 2011), and methanotrophic archaea and various Proteobacteria and Actinobacteria at other 605 mud volcano sites at various locations in the world (e.g. Yakimov et al., 2002, Martinez et al., 606 2006). In all these sites no microbes were detected that could be identified as pathogens, 607 while all our mud volcano sampling locations were clearly impacted by microbes from 608 shallower (and likely contaminated) water sources. The amount of cultivated bacteria was 609 relatively consistent, both aerobic and anaerobic, when comparing the sampling locations

610 (Figure 6). There were not much differences between the identified microbes in the different 611 sampling locations, which was the case for both non-pathogenic and pathogenic bacteria. 612 Exceptions were carbon dioxide fixating bacteria detected in all mud volcano samples but 613 BD-0-L, and denitrifying bacteria, which were only recovered at DW-2-100. Pathogens were 
614 collected from all environmental samples, even from these sampling locations that did seem

615 to get their water, at least primarily, from a deeper source (DW 1-0 and DW 2-0).

616

617 Microbial species identification based on cultivation and followed-up sequencing resulted in 618 many pathogenic strains (Table 6). While even a similarity of nearly $100 \%$ does not 619 necessarily mean that the new isolate is also pathogenic, the evidence from all the identified

620 strains together strongly suggests that the mud volcano samples are substantially impacted by 621 pathogens. Vibrio species were detected in all water samples except from the collected rain 622 water samples. While some of the identified Vibrio species might be benign, like Vibrio 623 natriegens, which is common in estuarine mud, and Vibrio neocaledonicus, known for 624 inhibiting corrosion (Moradi et al. 2014), most of them are not. Vibrio fluvialis, detected in 625 DW 1-0, DW 2-0, Di-b-0, and BD-0-L, is a pathogen commonly found in coastal 626 environments and is considered an emerging pathogen due to the diarrheal outbreaks it causes 627 (Lee et al. 1981, Ramamurthy et al., 2014). Vibrio alginolyticus, detected at DW 2-0, DW $2-$ 628 100, Di-b-0, is known to cause otitis and wound infections (Longo et al. 2012, Reilli et al. 629 2011). Also, the Vibrio species of furnissi and parahaemolyticus were found in Di-b-0, both 630 of which cause gastrointestinal illness (EHA 2019, Brenner et al 1983, Daniels et al. 2000, 631 Derber et al. 2011, Ballal et al. 2017).

632

633 Other pathogens from water samples were detected as well including Shewanella haliotis in 634 DW 2-0 and Di-b-0. This species was first isolated from the gut microflora of edible sea 635 snails (Kim et al. 2007), but more recently has been shown to be the cause of severe skin 636 infections (Poovorawan et al. 2013). Clostridium amygdalinum, an environmental, moderately 637 thermophilic anaerobic bacterium which can cause chronic ostitis (Carlier et al. 2006, 638 Parshina et al. 2003) was found in both water samples from DW 2 (at the surface and $100 \mathrm{~cm}$ 639 depth). Further, the known pathogen Enterococcus casseliflavus was detected at DW-2-100 
640 and Morganella morganii at Di-b-0, which is found in intestinal tracts of humans, mammals,

641 and reptiles, but also known to cause urinary infections (Reid et al., 2001; Miller, 2018).

643 It is instructional to compare the microorganisms collected from rain water with those

644 collected from the mud volcano samples. Neither Vibrio species nor any of the before

645 mentioned pathogens were detected in the rain water. However, there were some other

646 bacterial species of concern. These included two Pantoea species which belong to the family

647 of the Enterobacteriaceaea. One, Pantoea ananatis is a known plant pathogen (Coutinho and

648 Venter 2009). Another member of this family, Enterobacter cloacae, was also detected. This

649 microorganism has emerged as one of the most commonly found nosocomial pathogens in

650 neonatal units in recent years, with several outbreaks of infection being reported (Dalben et al.

651 2008). We also cultivated Klebsiella variicola, which occurs together with a number of

652 different plants including banana trees and sugarcane, but has also been isolated from cows 653 suffering from bovine mastitis (Podder et al. 2014) and from bloodstream infections

654 (Maatallah et al. 2009).

655 Whether the pathogens were mixed in directly by water flowing off the surface in the course 656 of extensive rainfall or from surface water/groundwater remains unknown, but given their 657 common occurrence a contamination with surface or near-surface water seems likely. A 658 deeper source of pathogens is unlikely, because (i) the pathogens would have no host in the 659 deep subsurface and (ii) previous isotopic gas analyses resulted in $\delta^{13} \mathrm{C}$ methane 660 concentrations ranging between -52 and $-33 \%$, thus implying that the gases are of purely 661 thermogenic nature - although not necessarily the pore water (with the possible exception of 662 Devil's Woodyard, which might have a slight bacterial component (Deville et al. 2003). Also, 663 (iii) no pathogens were detected at any other mud volcano sites. Instead methanotrophic 664 archaea und sulfate-reducing bacteria seem to be the typical microorganisms present 
665 (Niemann et al., 2006; Yakimov et al., 2002; Martinez et al., 2006; Lösekann et al., 2007; Liu

666 et al., 2011). Further strengthening this conclusion is that some pathogenic strains, albeit plant

667 pathogens (e.g., Pantoea sp.) were also identified in collected precipitation water (PAX).

668 Thus rain fall seems to be a major source of pathogenic load. Nevertheless, it appears that the 669 major load of human pathogens derives from shallow ground water or surficial water mixing 670 with the mud volcano fluids.

671

672

673

674

675

676

677

678

679

680

681

682

683

684

685

\section{Conclusions}

Different types of clustering of chemical components could be observed in liquid and solid mud volcano samples based on chemical analyses including isotopic compositions, but these were not related to their geological location, being north or south of the Los Bajos fault line. Isotopic and microbial analyses revealed that all of the mud volcanoes were chemically and microbially affected by precipitation or surficial water, even when drawing most of the water from deeper sources. In addition to sulfate-reducing bacteria and methanogenic archaea, we could identify pathogenic strains in all samples, including in the sampled rain water, meaning that even precipitation can be a source of pathogenic strains in Trinidad. However, diversity and abundance of pathogenic strains were much higher at sample locations that were in contact with surficial or near-surface ground water. Anthropogenic contamination is not necessarily implicated by our chemical and microbial results, but it is likely occurring at some of the locations. The observed pathogenic load in the environmental samples is a major health concern and should be investigated further.

\section{Acknowledgements}

This research was financially supported by ERC Advanced Grant HOME (No. 339231). We also acknowledge the help by Edward Guinan from Villanova University during the sampling campaign (he is pictured in Fig. 2a) and three anonymous reviewers who helped with their constructive comments to improve this paper. Also, we are thankful to Dr. Antonio 
Ramkissoon from the University of the West Indies for the culturing of some of the soil

695

696

697

698

699

700

701

702

703

704

705

706

707

708

709

710

711

712

713

714

715

716

717

718

719

720

721

722

723

724

725

726

727

728

729

730

731

732

733

734

735

736

737

738

739

740

samples.

\section{References}

Ballal, M., Shetty, V., Bangera, S.R., Prabhu, M., Umakanth, S., 2017. Vibrio furnissii, an emerging pathogen causing acute gastroenteritis: a Case Report. JMM Case Rep. 4(9), e005111, doi: 10.1099/jmmcr.0.005111

Bonanno, G., Giudice, R.L., Pavone, P., 2012. Trace element biomonitoring using mosses in urban areas affected by mud volcanoes around Mt. Etna. The case of the Salinelle, Italy. Environmental Monitoring and Assessment 184, 5181-5188.

Brenner, D.J., Hickman-Brenner, F.W., Lee, J.V., Steigerwalt, A.G., Fanning, G.R., Hollis, D.G., Farmer, J.J., Weaver, R.E., Joseph, S.W., Seidler, R.J., 1983. Vibrio furnissii (formerly aerogenic biogroup of Vibrio fluvialis), a new species isolated from human feces and the environment. Journal of Clinical Microbiology 18 (4), 816-824.

Carlier, J.-P., Manich, M., Loïez, C., Migaud, H., Courcol, R.J., 2006. First isolation of Clostridium amygdalinum from a patient with chronic osteitis. J Clin Microbiol. 44(10), 3842-3844. doi: 10.1128/JCM.01200-06

Chao, H.-C., You, C.-F., Sun, C.-H., 2010. Gases in Taiwan mud volcanoes: chemical composition, methane carbon isotopes, and gas fluxes. Applied Geochemistry 25, 428436.

Cho, B.C., Jang, G.I., 2014. Active and diverse rainwater bacteria collected at an inland site in spring and summer 2011. Atmospheric Environment 94, 409-416.

Constantinidou, H.A., Hirano, S.S., Baker, L.S., Upper, C.D., 1990. Atmospheric dispersal of ice nucleation-active bacteria: the role of rain. Phytopathology 80, 934-937.

Coutinho, T.A., Venter, S.N., 2009. Pantoea ananatis: an unconventional plant pathogen. Mol Plant Pathol. 10, 325-335. doi: 10.1111/j.1364-3703.2009.00542.x.

Dalben, M., Varkulja, G., Basso, M., Krebs, V.L.J., Gibelli, M.A., van der Heijden, I., Rossi, F., Duboc, G., Levin, A.S., Costa, S.F., 2008. Investigation of an outbreak of Enterobacter cloacae in a neonatal unit and review of the literature. J. Hosp. Infect.70, $7-14$. 
Daniels, N.A., Shafaie, A., 2000. A review of pathogenic Vibrio infections for clinicians. Infections in Medicine 17, 665-685.

Derber, C., Coudron, P., Tarr, C., Gladney, L., Turnsek, M., Shankaran, S., Wong, E., 2011. Vibrio furnissii: an unusual cause of bacteremia and skin lesions after ingestion of seafood. Journal of Clinical Microbiology 49, 2348-2349. doi:10.1128/JCM.0009211.

Deville, E., Battani, A., Griboulard, R., Guerlais, S., Herbin, J.P., Houzay, J.P., Muller, C., Prinzhofer, A., 2003. The origin and processes of mud volcanism: new insights from Trinidad. Geological Society London, Special Publications 216, 475-490.

Deville, E., Guerlais, S.-H., 2009, Cyclic activity of mud volcanoes: evidences from Trinidad (SE Caribbean). Marine and Petroleum Geology 26, 1681-1691.

Dia, A.N., Castrec-Rouelle, M., Boulègue, J., Comeau, P., 1999. Trinidad mud volcanoes: where do the expelled fluids come from? Geochimica et Cosmochimica Acta 63, 1023-1038. doi.org/10.1016/S0016-7037(98)00309-3

Dimitrov, L.I., 2002. Mud volcanoes- the most important pathway for degassing deeply buried sediments. Earth-Science Reviews 59, 49-76.

Direito, S.O.L., Marees, A., Röling, W.F.M., 2012. Sensitive life detection strategies for lowbiomass environments: optimizing extraction of nucleic acids adsorbing to terrestrial and Mars analogue minerals. FEMS Microbiol. Ecol. 81, 111-123. doi: 10.1111/j.1574-6941.2012.01325.x

EHA consulting, 2019. Website https://www.ehagroup.com/resources/pathogens/vibrioparahaemolyticus/, accessed 11 June 2019.

Evans, C.A., Coombes, P.J, Dunstan, R.H., 2006. Wind, rain and bacteria: The effect of weather on the microbial composition of roof-harvested rainwater. Water Research 40, $37-44$.

Geets, J., Borrernans, B., Diels, L., Springael, D., Vangronsveld, J., Van Der Lelie, D., et al., 2006. DsrB gene-based DGGE for community and diversity surveys of sulfatereducing bacteria. J. Microbiol. Methods 66, 194-205. doi: 10.1016/j.mimet.2005.11.002

Handle, F., Harir, M., Füssl, J., Koyun, A.N., Grossegger, D., Hertkorn, N., Eberhardsteiner, L., Hofko, B., Hospodka, M., Blab, R., Schmitt-Kopplin, P., Grothe, H., 2017. Tracking ageing of bitumen and its SARA fractions using high-field FT-ICR mass spectrometry. Energy \& Fuels 31, 4771-4779.

Hu, W., Murata, K., Zhang, D., 2017. Applicability of LIVE/DEAD BacLight stain with glutaraldehyde fixation for the measurement of bacterial abundance and viability in rainwater. Journal of Environmental Sciences 51, 202-213.

Jacobsen, C.S., 1995. Microscale detection of specific bacterial DNA in soil with a magnetic capture hybridization and PCR amplification assay. Applied and Environmental Microbiology 61, 3347-3352. 
Jennerjahn, T.C., Jänen, I., Propp, C., Adi, S., Nugroho, S.P., 2013. Environmental impact of mud volcano inputs on the anthropogenically altered Porong River and Madura Strait coastal waters, Java, Indonesia. Estuarine, Coastal and Shelf Science 130, 152-160.

Kaushik, R., Balasubramanian R., Dunstan, H., 2014. Microbial quality and phylogenetic diversity of fresh rainwater and tropical freshwater reservoir. PLoS ONE 9, e100737.

Kim, D., Baik, K.S., Kim, M.S., Jung, B.-M., Shin, T.-S., Chung, G.-H., Rhee, M.S., Seong, N.C., 2007. Shewanella haliotis sp. nov., isolated from the gut microflora of abalone, Haliotis discus hannai". Int J Syst Evol Microbiol. 57, 2926-2931. doi:10.1099/ijs.0.65257-0.

Kioka, A., Ashi, J., 2015. Episodic massive mud eruptions from submarine mud volcanoes examined through topographical signatures. Geophysical Research Letters 42, 84068414.

Koeniger, P., Marshall, J.D., Link, T., Mulch, A., 2011. An inexpensive, fast, and reliable method for vacuum extraction of soil and plant water for stable isotope analyses by mass spectrometry. Rapid Communications in Mass Spectrometry 25, 3041-3048. doi: $10.1002 / \mathrm{rcm} .5198$.

Kokh, S.N., Sokol, E.V., Dekterev, A.A., Kokh, K.A., Rashidov, T.M., Tomilenko, A.A., Bul'bak, T.A., Khasaeva, A., Guseinov, A., 2017. The 2011 strong fire eruption of Shikhzarli mud volcano, Azerbaijan: a case study with implications for methane flux estimation. Environmental Earth Science, 76: 701.

Kopf, A., 2002. Significance of mud Volcanism. Review of Geophysics 40, 2-1 - 2-52.

Lee, J.V., Shread, P., Furniss, A.L., Bryant, T.N., 1981. Taxonomy and description of Vibrio fluvialis sp. nov. (synonym group F. vibrios, group EF6). Journal of Applied Microbiology 50, 73-94. doi:10.1111/j.1365-2672.1981.tb00873.x

Liu, C.-C., Jean, J.-S., Nath, B., Lee, M.-K., Hor, L.-I., Lin, K.-H., Maitya, J.P., 2009. Geochemical characteristics of the fluids and muds from two southern Taiwan mud volcanoes: Implications for water-sediment interaction and groundwater arsenic enrichment. Applied Geochemistry 24,1793-1802.

Liu, C.-C., Maitya, J.P., Jean, J.-S., Sracek, O., Kar, S., Li, Z., 2011. Biogeochemical interactions among the arsenic, iron, humic substances, and microbes in mud volcano.es in southern Taiwan. Journal of Environmental Science and Heath 46, 12181230.

Liu, C.-C., Maitya, J.P., Jean, J.-S., Li, Z., Kar, S., Sracek, O., Yang, H.-J., Chen, C.Y., Selim Reza, A.H.M., Bundschuh, J., Lee, C.-Y., 2013. The geochemical characteristics of the mud liquids in the Wushanting and Hsiaokunshui mud volcano region in southern Taiwan: implications of humic substances for binding and mobilization of arsenic. Journal of Geochemical Exploration 128, 62-71.

Longo, D., Fauci, A.S., Kasper, D.L., 2012. Harrison's Principles of Internal Medicine, 18th edition, McGraw-Hill Professional. 
Lösekann, T., Knittel, K., Nadalig, T., Fuchs, B., Niemann, H., Boetius, A., Amann, R., 2007. Diversity and abundance of aerobic and anaerobic methane oxidizers at the Haakon Mosby mud volcano, Barents Sea. Applied and Environmental Microbiology 73, 3348-3362.

Lucio, M., 2009. Datamining metabolomics: the convergence point of non-target approach and statistical investigation. http://nbn-resolving.de/urn:nbn:de:bvb:91-diss-20080916673608-1-4.

Maatallah, M.' Vading, M., Kabir, M.H., Bakhrouf, A., Kalin, M., Nauclér, P., Brisse, S., Giske, C.G., 2009. Klebsiella variicola is a frequent cause of bloodstream infection in the Stockholm area, and associated with higher mortality compared to K. pneumonia . Mol Plant Pathol. 10, 325-335. doi: 10.1111/j.1364-3703.2009.00542.x.

Martinez, R.J., Mills, H.J., Story, S., Sobecky, P.A., 2006. Prokaryotic diversity and metabolically active microbial populations in sediments from an active mud volcano in the Gulf of Mexico. Environmental Microbiology 8, 1783-1796.

Mazzini, A., Etiope, G., 2017. Mud volcanism: An updated review. Earth-Science Reviews 168, 81-112. doi.org/10.1016/j.earscirev.2017.03.001

Meckenstock, R.U., von Netzer, F., Stumpp, C., Lueders, T., Himmelberg, A.M., Hertkorn, N., Schmitt-Kopplin, P., Harir, M., Hosein, R., Haque, S., Schulze-Makuch, D., 2014. Water droplets in oil are microhabitats for microbial life. Science 345, 673-676. doi: $10.1126 /$ science. 1252215

Mieiro, C.L., Pato, P., Pereira, E., Mirante, F., Coutinho, J.A.P., Pinheiro, L.M., Magalhães, V.H., Duarte, A.C., Abuter, R., 2007. Total mercury in sediments from mud volcanoes in Gulf of Cadiz. Marine Pollution Bulletin 54, 1539-1544.

Milkov, A.V., Sassen, R., Apanasovich, T.V., Dadashev, F.G., 2003. Global gas flux from mud volcanoes: A significant source of fossil methane in the atmosphere and the ocean. Geophysical Research Letters 3, 1037-1040.

Miller, J.R., 2018. Morganella infections. https://emedicine.medscape.com/article/222443overview\#a0101, updated 29 Nov 2018.

Moradi, M., Song, Z., Tao, X. Introducing a novel bacterium, Vibrio neocaledonicus sp., with the highest corrosion inhibition efficiency. Electrochemistry Communications 51, 6468.

Nadkarni M.A., Martin, F.E., Jacques, N.A., Hunter, N., 2002. Determination of bacterial load by real-time PCR using a broad-range (universal) probe and primers set. Microbiology 148, 257-266.

Niemann, H., Lösekann, T., de Beer, D., Elvert, M., Nadalig, T., Knittel, K., Amann, R., Sauter, E.J., Schlüter, M., Klages, M., Foucher, J.P., Boetius, A., 2006. Novel microbial communities of the Haakon Mosby mud volcano and their role as methane sink. Nature 443. doi:10.1038/nature05227. 
Orlowski, N., Breuer, L., Angeli, N., Boeckx, P., Brumbt, C., Cook, C.S., Dubbert, M., Dyckmans, J., Gallagher,B., Gralher, B., Herbstritt, B., Hervé-Fernández,P., Hissler, C., Koeniger, P., Legout, A., Macdonald, C.J., Oyarzún, C., Redelstein, R., Seidler, C., Siegwolf, R., Stumpp, C., Thomsen, S., Weiler, M., Werner, C., McDonnell, J.J., 2018. Inter-laboratory comparison of cryogenic water extraction systems for stable isotope analysis of soil water. Hydrology and Earth System Sciences 22, 3619-3637. doi: 10.5194/hess-22-3619-2018

Parshina, S.N., Kleerebezem, R., Sanz, J.L., Lettinga, G., Nozhevnikova, A.N., Kostrikina, N.A., Lysenko, A.M., Stams, A.J., 2003. Soehngenia saccharolytica gen. nov., sp. nov. and Clostridium amygdalinum sp. nov., two novel anaerobic, benzaldehyde-converting bacteria. International Journal of Systematic and Evolutionary Microbiology 53, 1791-1799. doi:10.1099/ijs.0.02668-0.

Peters, E.J., 2011. Water quality of rainwater cisterns in the Grenadines. The West Indian Journal of Engineering 33, 56-64.

Plumlee, G.S., Casadevall, T.J., Wibowo, H.T., Rosenbauer, R.J., Johnson, C.A., Breit, G.N., Lowers, H.A., Wolf, R.E., Hageman, P.L., Goldstein, H., Anthony, M.W., Berry, C.J., Fey, D.L., Meeker, G.P., and Morman, S.A., 2008. Preliminary analytical results for a mud sample collected from the LUSI mud volcano, Sidoarjo, East Java, Indonesia: U.S. Geological Survey Open-File Report 2008-1019, Reston, VA, U.S.A. https://pubs.usgs.gov/of/2008/1019/pdf/OF08-1019_508.pdf.

Podder, M.P., Rogers, L., Daley, P.K., Keefe, G.P., Whitney, H.G., Tahlan, K., 2014. Klebsiella species associated with bovine mastitis in Newfoundland. PLoS ONE 9, e106518. Bibcode:2014PLoSO...9j6518P. doi:10.1371/journal.pone.0106518.

Poovorawan, K., Chatsuwan, T., Lakananurak, N., Chansaenroj, J., Komolmit, P., Poovorawan, Y., 2013. Shewanella haliotis associated with severe soft tissue infection, Thailand. Emerging Infectious Diseases 19, 1019-1021. doi:10.3201/eid1906.121607.

Ramamurthy, T., Chowdhury, G., Pazhani, G.P., Shinoda, S., 2014. Vibrio fluvialis: an emerging human pathogen. Front Microbiol. 5, 91. doi: 10.3389/fmicb.2014.00091

Reid, K.C., Cockerill, F.R., and Patel, R. (2001) Clinical and epidemiological features of Enterococcus casseliflavus/flavescens and Enterococcus gallinarum bacteremia: a report of 20 cases. Clinical Infectious Diseases 32: 1540-1546, doi.org/10.1086/320542

Reilly, G.D., Reilly, C.A., Smith, E.G., Baker-Austin, C., 2011. Vibrio alginolyticusassociated wound infection acquired in British waters, Guernsey. Euro Surveill. 16 (42).

Saunders, R., Mellowes, W., Clarke, R., Kimkeran, K., 2003. Application of SODIS technology to rain and tap water samples from Mayaro, Trinidad \& Tobago, in Litter, M.I., Mansilla, H.D. (Eds.), Solar Disinfection of Water in Rural Communities of Latin America. Agencia Interamericana para la Coooperación y el Desarrollo, pp. 8387. http://www.iiap.org.pe/upload/publicacion/PUBL438.pdf\#page=84. 
Sauter, E.J., Muyakshin, S.I., Charlou, L.C., Schlüter, M., Boetius, A., Jerosch, K., Damm, E., Foucher, J.-P., Klages, M., 2006. Methane discharge from a deep-sea submarine mud volcano into the upper water column by gas hydrate-coated methane bubbles. Earth Planet. Sci. Letters 243, 354-365.

Schmitt-Kopplin, P., Kiss, G., Dabek-Zlotorzynska, E., Gelencsér, A., Hertkorn, N., Harir, M., Hong, Y., Gebefügi, I., 2010. Analysis of the unresolved organic fraction in atmospheric aerosols with ultrahigh-resolution mass spectrometry and nuclear magnetic resonance spectroscopy: organosulfates as photochemical smog constituents. Anal Chem. 82, 8017-8026.

Schulze-Makuch, D., Goodell, P., Kretzschmar, T. Kennedy, J.F., 2003. Microbial and chemical characterization of a groundwater flow system in an intermontane basin of southern New Mexico. Hydrogeology Journal 11, 401-412.

Selesi, D., Schmid, M., Hartmann, A., 2005. Diversity of green-like and red-like ribulose-1,5bisphosphate carboxylase/oxygenase large-subunit genes (cbbL) in differently managed agricultural soils. Appl. Environ. Microbiol. 71, 175-184

Selesi, D., Pattis, I., Schmid, M., Kandeler, E., Hartmann, A., 2007. Quantification of bacterial Rubisco genes in soil by cbbL targeted real-time PCR. J. Microbiol. Methods 69, 497-503. doi: 10.1016/j.mimet.2007.03.002.

Smith, G.A., Nickels, J.S., Kerger, R., 1986. Quantitative characterization of microbial biomass and community structure in subsurface material: a prokaryotic consortium responsive to organic contamination. Can J Microbiol 32, 104-111.

Smith, C.J., Nedwell, D.B., Dong, L.F., Osborn, A.M., 2007. Diversity and abundance of nitrate reductase genes (narG and napA), nitrite reductase genes (nirS and nrfA), and their transcripts in estuarine sediments. Appl Environ Microbiol. 73, 3612-3622.

Steinberg, L.M., Regan, J.M., 2008. Phylogenetic comparison of the methanogenic communities from an acidic, oligotrophic fen and an anaerobic digester treating municipal wastewater sludge. Appl Environ Microbiol 74, 6663-6671.

Sundar, R., Darsan, J., 2019, A geomorphological analysis of the Piparo and Digity mud volcanoes in south Trinidad. Caribbean Journal of Earth Science 49, 23-34.

Tziotis, D., Hertkorn, N., Schmitt-Kopplin, P., 2011. Kendrick-analogous network visualization of ion cyclotron resonance Fourier transform mass spectra: improved options for the assignment of elemental compositions and the classification of organic molecular complexity. EJMS 17, 415-421

Welch, P., David, J., Clarke, W., Trinidade, A., Penner, D., Bernstein, S., Mcdougall, L., and Adesiyun, A.A., 2000. Microbial quality of water in rural communities of Trinidad. Pan American Journal of Public Health 8, 172-180.

White, D.C., Flemming, C.A., Leung, K.T., Macnaughton, S.J., 1998. In situ microbial ecology for quantitative appraisal, monitoring, and risk assessment of pollution remediation in soils, the subsurface, the rhizosphere and in biofilms. J. Microbiol. Method 32, 93-105. 
997 Yakimov, M.M., Giuliano, L., Crisafi, E., Chernikova, T.N., Timmis, K.N., Golyshin, P.N., 998 2002. Microbial community of a saline mud volcano at San Biagio-Belpasso, Mt. Etna 999 